\title{
Sciendo
}

\section{Introduction to diplomatic Sciences (handbook and glossary).}

\author{
Alessandro Figus \\ prof. PhD drHc International Institute of Management IMI-Nova (Moldova) and Link Campus \\ University(Italy)-email: a.figus@unilink.it
}

Doi: $10.2478 /$ gssfj-2018-0001

\begin{abstract}
This is a work between a very short introduction and handbook to understand what diplomacy is and to study it. The author introduces diplomacy to start form historical perspective and to provide significant examples to illustrate the art of diplomacy in action. Diplomacy has evolved greatly, coming to mean diverse things, to different persons, at several time, reaching from the sophisticated to inelegant and ordinary. this paper presents the first attempts to measure student learning quantitatively by administering a pre-test, post-test survey supplemented by a glossary of diplomatic terms.
\end{abstract}

Keywords: diplomacy, diplomatic sciences, foreign policy

\section{Introduction to diplomacy}

The main question that one must ask is: why study diplomatic sciences and what is the importance of diplomacy?

Today, it is actually important to study diplomacy because it is essential in international relations since national interest cannot be defended without being diplomatic, and not at all can cooperation work with other countries when diplomacy lacks. This is the key significance of diplomacy. In international relations, it is sometimes defined as soft power, and it contrasts all out disorder, namely hard power: war. Etymologically, the term diplomacy most likely derives from the ancient Greek word "diploun" (for twofold or double) that was used in connection with diplomas, special documents carried by religious envoys that were supposed to ensure a safe journey (see Sascha Lohmann Understanding Diplomacy in the 21st Century, German Institute for International and Security Affairs, 2017)

We have a lot of definitions of diplomacy but according to the the Oxford Living Dictionaries, diplomacy is "the profession, activity, or skill of managing international relations, typically by a country's representatives abroad", but also "the art of dealing with people in a sensitive and tactful way".

Diplomacy can also be defined as being "the conduct by government officials of negotiations and other relations between nations" (dictionary .com).

States use diplomacy with the intention to solve disputes, form alliances, negotiate treaties, fortify economic relations, stimulate cultural and military exchanges, and for a variety of other aims. This activity is typically carried out by a country's 
representative abroad. Diplomacy includes a broad arrangement of several rules, etiquettes, goals, procedures, and agreements too, so much so that diplomacy has become the governance of all international relations and is also closely related to the state and its government. As certain nations expanded their borders and spheres of influence, they enlarged their control over trade and industry and became more powerful under a military point of view. Other nations, fearful of the power of their neighbours, sought ways to expand their boundaries or zones of influence to balance those of their neighbours. As a result of the factors already mentioned along with others not mentioned, an international struggle developed among the nations for land, natural resources, and populations. As a natural consequence, the expansion of governmental units led to the maintenance of internal peace to a greater extent than when the regions were composed of many small governmental units. This was especially true when the government was suitable to a majority of the population, and when freedom of travel and trade were gained through said expansion. Thus, it may be said that two conditions are necessary for peace, namely, political unity and economic freedom. However, as the individual political units became larger and more powerful, the wars that were financed among the states became more destructive of life and property and involved the entire world instead of small parts of it. The need for establishing agencies and methods for preserving peaceful relationship between nations became progressively apparent. Methods to avoid wars and to regulate "International Relations Society" have attempted in various ways to maintain peaceful relations between the states. Some nations have attempted to become so powerful and so autonomous that no other country would dare to engage in wars against them. Some states have attempted to sustain peace through other means. One of the oldest and most extensively used methods of establishing and maintaining international cooperation has been through diplomacy. "Diplomacy" has played a central role in the way nations interact and relate with other nations of the world. Indeed, diplomacy is based on the premise that the Nation does exist, and to the latter national interest, that is the interest of its citizens, is ascribable. This is one of the reasons why now it is important to study international relations, not to be mistaken with political science, which is concerned with the domestic affairs of a state.

All modern states sustain official contacts with other states with which they are at peace through the exchange of representatives or agents. The agents which are sent to represent a state in another country are of two main classes: diplomatic and consular. Diplomatic representatives are political agents and maintain relations, as well as consult, with the governments; consular agents, on the other hand, are commercial representatives and take care of trade relations between the two countries, protect citizens traveling in foreign countries, and enforce customs and immigration laws. The seat of the diplomatic service is located in the capital of the country in which it is operating; the consular service, on the other hand, is located in large cities, especially port cities and/or cities that guarantee entrance into the countries. There is a structured rank of diplomatic and consular agents. In order to 
avoid confusion and controversy between representatives of different states over questions of precedence and dignity, a definite system of ranking diplomatic agents was established at first by the Congresses of Vienna (1815) and then by Aix-la Chapelle (1818) and has been followed since then. According to this plan, there are four classes of diplomatic agents now recognized in order of rank as follows: a) ambassadors; b) envoys and ministers; c) ministers' resident (a class occasionally used today); d) chargés d'affaires. As a general practice, ambassadors are received only from sovereign states.

In addition to the establishment of four classes of diplomatic representatives, above mentioned, two additional practices have been adopted by the United States and other nations. In case of representatives of equal rank, the one enjoying the longest period of service or seniority shall have precedence over others. Other classes of the diplomatic service likewise rank in accordance with tenure in office. The second practice which has been widely followed is that of sending a diplomatic representative, or one of the same rank as that of the country to which the representative is being sent. Usually the consular service in foreign countries is divided into five categories as follows: a) Consul generals at large, who travel through a particular region to inspect the consular posts; b) Consul generals, who are responsible for the consular activities of a particular area, usually an entire nation; c) Consuls, who handle the col-mint activities in the more important commercial centres; d) Vice-consuls, who serve as subordinate officers and assistants at the principal consulates or as head of consulates in smaller cities; e) Consular agents, who serve in consular posts that do not require the services of a full-time agent. The personnel, except that with policy-determining functions, of both the diplomatic and consular services are selected on the basis of competitive civil service examinations and are protected by civil service rating, with provisions for promotions and usually retire at the age of sixty-five years. The ambassadors, ministers, and consuls are appointed by the Government, as is the case in Italy. In the USA, however, they are appointed by the President with the approval of the Senate. Exchange of foreign service agents between nations is carried out only when countries are at peace with each other. One of the first acts of war is usually the breaking off of diplomatic relations between the countries involved, which means that the representatives in the respective countries are called back or sent home. Sometimes a government of a particular country is distasteful to another country to such an extent that the other country refuses to "recognise" that government. That may happen when a reposition has unseated the former rulers and established a new administration in power. When such conditions arise, there is no exchange of diplomatic or consular representatives. The individuals that a nation sends to another nation as its representatives must be accepted by the countries in which the agents are to serve. The reasons why an individual is not accepted need not be made public. It is sufficient to require an ambassador or representative of lower rank to be recalled to his homeland, or for him not to be accepted as a representative, if he 
is officially declared to be persona non grata (meaning a not accepted person) to the country in which he is serving or is expected to serve.

\subsection{Functions of the diplomatic representative}

The main function of a diplomatic agent in a country is to attempt in every possible way to advance the interests of his country in the area to which he is sent. Moreover, he tries to create good will towards his country; increase or develop international confidence in his state; encourage cooperation; bring to the forefront common interests between his state and the country in which he serves; allay fears; be alert to find out influences which weaken international solidarity of action to the disadvantage of his own country and ultimately remove or weaken those forces; and to maintain friendly relations with the press. The ambassador and diplomats of lesser rank are to look and listen to what is going on in the nation in which they are stationed and to report it fully and accurately to the proper officials at home. In turn, the homeland sends messages to the proper governmental officials of a foreign country through the diplomatic representatives within that country.

A method of attempting to maintain peace, which is about as old as the state itself, is the application of the principle of Balance of Power. The principle simply means that while all nations are competing for power, there is widespread effort to prevent any one nation or any combination of nations from becoming so powerful that it or they can individually or collectively endanger the other powers. Through the operation of balance of power, no state has been able, in modern times, to conquer the world.

Every community, every association of individuals imposes rules on its members (MacIver, post-war problems, 1945). The above statement is true whether it refers to a family, village, city, nation, or the world. Where there are no rules to guide and control human behaviour, a condition of anarchy and chaos is to be found. To control or to guide the relationships between states, an elaborate system of international laws has been developed.

\subsection{Origin of international law}

The development of international trade that followed the Crusades, the discovery of new continents, and the settlement and exploitation of the riches in new territories, led to a great deal of economic competition and conflict among nations. Today the tendency in the academic world is to adequately describe the vast body of international laws and practices.

\subsection{Character of international law}

International law is different from the laws of a state in several respects. No legislative bodies, such as congresses or parliaments, pass international laws. Instead, 
international laws arise as agreements accepted by parties - states — of equal status. State laws are designed primarily to regulate the behaviour of individuals, groups, or organizations of individuals living within the country; international laws deal with the actions of states in their relationship with other states. International law is concerned with such matters as what qualities a state must possess to be entitled to membership in the community of states (states are admitted to status in the community of states when diplomatic recognition is extended to them by other states); what constitutes sovereignty of the state; ceremonial matters connected with the heads of states and diplomatic agents; jurisdiction of states in certain matters (territorial waters, on the high seas, over foreign ships in port, over aliens); relations between states in time of war.

State laws are administered and interpreted by the executive branch of the government with the assistance and advice of various courts. International laws are interpreted by the foreign offices of the various states concerned. For example, the State Department of the United States with its various branches at home and abroad interprets international laws in so far as they affect the United States. In rare cases, when two states cannot agree as to the meaning and intent of international law as it affects them, the question may be referred to an arbitration tribunal or to the Permanent Court of International Justice, in French "la Cour internationale de justice", commonly referred to as the World Court, ICJ or The Hague. It is the primary judicial branch of the United Nations (UN). Seated in the Peace Palace in The Hague, Netherlands, the court settles legal disputes submitted to it by states and provides advisory opinions on legal questions submitted to it by duly authorized international branches, agencies, and the UN General Assembly. It is to be noted, however, that, before the case can go to either type of court for decision, the nations involved must give their assent to the procedure.

Another difference between state and international laws concerns the practice of enforcement. The state has its police force coupled with its systems of courts and penal institutions to enforce its statutes. International law has no enforcement agencies. Each state determines for itself whether it will or will not abide by the regulations and practices that have been established. There is no force, except the fear of war, to compel observance of international law by a state.

\subsection{Sources of international law}

There are four basic sources of international law. The most important source, in the sense that it has produced more laws than any other, is custom. Through common and accepted practice, custom comes to have the force of law and in time it is accepted as a law. A second source of international law is reason, which means that when a situation arises for which there are no established rules, then deductions shall be made from established principles or from some similar situations for which rules have been formulated. The third source is authority. Decisions and verdicts which have been made by legally constituted tribunals, such as courts or boards of 
arbitration, and the opinions of recognized authorities in the field of international law, are sources of international law.

The fourth source is by agreement between or among states, that comes as a result of negotiations and usually in the form of written communiques. A treaty may set up certain practices, conditions, or principles which are accepted by the signatories. These treaty agreements provide a very important source of international law, since they spell out the actions and responsibilities of each side regarding mutual interest. Where a number of states agree to rules of conduct under certain conditions, the treaty agreements are accepted as part of the international regulations.

On the other hand, where two states make a treaty for a particular period of time or on a special subject, such an agreement cannot be regarded as constituting international law. In some cases, treaties are made in order to avoid or to set aside international rules so far as particular provisions apply to the specific countries.

The practice of treaty-making between states is of great antiquity, but the use of treaties has increased greatly within the past hundred years.

\subsection{Other forms of international agreement}

In addition to the formal types of agreements between states there are other less formal forms such as: conventions, protocols, declarations, armistices, cartels, compromises, and executive agreements. Conventions are less formal agreements than treaties, which usually relate to more specific and technical matters. It is often left to the discretion of the negotiators as to whether the agreement will be in the form of a treaty or of a convention.

Protocol is a term applied to an agreement less formal than either a treaty or a convention. The term sometimes applies to preliminary drafts of agreements signed in anticipation of the preparation of more formal documents later. Declarations are statements of two or more states setting forth a common conception of certain principles of international law. The term may also refer to the statement of a policy to be followed by a particular government. In the latter case it does not constitute an international agreement. Armistice is an agreement between combatant forces to suspend hostilities at a certain time.

Cartels are agreements entered into force between belligerent states for such purposes as the exchange of prisoners of war. Compromise is an agreement between states to submit a dispute to arbitration. Executive agreements are made by the executives of two or more countries with the understanding that the agreement is simply between the executives and does not bind the state in case a new executive takes office. 


\subsection{Procedure in treaty-making}

The making of treaties has been formalized through usage and involves adherence to a well-established order of procedures which must be followed if the agreements are to be valid.

The negotiators who represent their respective countries meet and establish their right to serve as representatives of their states through the credentials they bear. The negotiators may be members of the established embassy or may be special diplomatic representatives.

The negotiations are transacted and the agreement is signed by the agents. It is then transmitted to the respective countries for ratification by the proper authorities in the United States all treaties must have the approval of two-thirds of the members of the Senate present.

Ratification of the agreement may be withheld or reservations and amendments may be attached by the ratifying authorities. Such reservations and amendments must be accepted, if they are to be binding, by the other power or powers. The negotiating parties then exchange ratifications in a formal ceremony and pledge to one another that each will faithfully execute the terms of the agreement. The final step in the procedure is the formal promulgation of the treaty and its actual execution.

\subsection{Enforcement of treaties}

The enforcement of treaties among nations is similar to the enforcement of international law. The word or guarantee of a state is all that the other states have to ensure fulfilment of treaty obligations. There is no police or other force to require a state to fulfil its responsibilities under the terms of any form of international agreement. In most cases the states do abide by the terms of treaties and execute them faithfully.

It is inevitable that people and states carrying on businesses and other forms of interaction together incur into disagreements. These may be brought to a satisfactory solution through various forms of negotiation. Many international disputes have been thus solved. Negotiation may be carried out through regular diplomatic channels established between the disputants, or it may be conducted by special agents appointed to meet somewhere accepted by both parties to the dispute. If agreement is reached, the decisions may be incorporated into a treaty or some other less formal international engagement. However, if agreement is not reached, help may be brought about through mediation or arbitration.

\subsection{Mediation}

In many instances, the agents of the disputing states are unable to reach an agreement and relations between them become "strained." A third state, which is in good terms with the disputants, may then make a "tender of good offices" in order 
to help them reach a peaceful settlement of their difficulties. Such an offer is merely a polite inquiry by the outside party as to whether it can be of service to the disputing parties in reaching an agreement to their dispute. If the disputants accept the offer of the neutral state, it may attempt to find grounds for settlement of the differences upon which the disputants can agree.

\subsection{Arbitration}

Sometimes when two states cannot reach a peaceful solution regarding their disagreements, they agree to submit the matter to an arbitrator. The latter may be an individual, like the Pope or the head of some friendly state, or it may be a committee made up of a specific number of representatives of friendly neutral states. Article 37 of "The Hague Convention" for the Pacific Settlement of International Disputes defines arbitration as follows: "International arbitration has for its object the settlement of disputes between states by judges of their own choice, and on the basis of respect for law. Recourse to arbitration implies an engagement to submit in good faith to the award."

This definition identifies four elements which are characteristic of arbitration as follows: (1) the settlement of disputes between states is by their own voluntary action; (2) by judges which they themselves choose; (3) on the basis of respect for law (which implies that the arbitrators may go beyond the strict letter of international law in their deliberations and may consider extra-legal facts which they regard as relevant to the controversy); (4) the disputants obligate themselves in advance to abide by the decision of the judges. Arbitration has an advantage over mediation in that the disputants agree in advance to submit to the decision of the arbitrators; a peaceful settlement of the problem is thus assured. Serious difficulties stand in the way of large scale and successful use of arbitration as a means of avoiding war.

States are seldom willing to allow a third party a free hand in the settlement of their disputes; this is especially true if the matters are regarded as serious or if the "national honour" is involved. Another difficulty inherent in the use of arbitration as it has been employed, is the matter of securing well-qualified arbitrators to handle the problems skilfully. In order to meet this difficulty, "The Hague Permanent Court of Arbitration" was established in 1899. In a strict sense this was not a court in which the jurists were in regular or continuous session. Instead, it was a list or panel of names of persons designated by different countries as well-qualified and willing-toserve arbitrators.

When individuals disagree, an amicable solution can be achieved by getting the disputants, or their personal representatives, to meet, rather than take their troubles to court.

The same process, known as conference or congress when applied at a state level, has been successfully utilized in international affairs. Whenever the representatives of two or more states meet to settle an international dispute through the process of 
discussion and mutual agreement, without the use of arbitration or other judicial process, such a meeting may be called a conference.

Until fairly recent times, international conferences were held only by nations at war with one another with the purpose of reaching peaceful arrangements.

In more recent times, conferences have been utilized by nations at peace with the purpose of gaining mutual understanding on a great variety of subjects and reaching agreements on future policies and actions in the fields considered.

\section{Why study diplomacy}

1. Cohabitation of separate political units requires a certain degree of contact among them.

2. Communication between the governments to guarantee regular and standard international process.

3. Instruments of foreign policy.

4. Use of soft power as an alternative to disorder.

5. Diplomacy has become the governance of all international relations.

The foreign policy of a state consists of self-interest strategies, adopted by the state to protect the national interest, and the achievement of its goals within the international system, so as to have full interaction among states.

The old bipolar world has given way to an international environment characterized by new instabilities and new uncertainties. As a result, diplomacy too is changing, and it is no longer sufficient to maintain traditional bilateral cooperation between states. All states need to optimize the benefits of multilateral international relations. Diplomacy is the central problem in international relations because without diplomacy national interest cannot be protected and neither can cooperation with other states take place. This is the core significance of diplomacy.

Determinants of foreign policy

- Geography and geopolitics

- History and culture

- Economic development

- National interest

- National character

- National ethics

- Political system

- Social system and Welfare

- Ideology

- Public opinion and media 
- Power and soft power

\subsection{The term diplomacy}

As previously mentioned, etymologically, the term diplomacy most likely derives from the ancient Greek word diploun (for twofold or double) that was used in connection with diplomas (special documents carried by religious envoys that were supposed to ensure a safe journey, see Sasha Lohmann, Understanding Diplomacy in the 21st Century, German Institute for International and Security Affairs, 2017).

Diplomacy is the art of conducting negotiations and other relations between representatives of states.

This activity is typically carried out by countries' representatives abroad.

The ability to practice diplomacy is one of the major components of a state. Diplomacy has been practiced since the creation of the first states, therefore in Roman times and even before.

At that time, a state could either manage to obtain what it wanted through negotiations or armed conflict.

However, to conduct negotiations, states would employ temporary envoys usually protected by their status. Later, the envoys became local standing Embassies, with staff in charge of day to day affairs.

The beginning of this evolution can be identified with the fifteenth century in Europe, the Renaissance, characterized by the establishment of innovative structures, despite the formal continuity with the past.

In that period, diplomacy started to adopt new structures that were not only in relation with the sovereignty of the state, but also with other organisms.

Indeed, originally diplomats were sent only for detailed negotiations, and would return directly after their mission was concluded. Diplomats could enjoy more prestige and consensus especially when they belonged to dominant families.

In conclusion, diplomacy is the management of international relations by negotiation, based on reciprocal knowledge and compromise.

\section{The history of diplomacy from an Italian perspective}

Conflicts most likely exist since the first organized groups of men were formed. The world felt the need to send, since that time, emissaries to propose ceasefires to the fighters. It is indisputable that the diplomatic activity was carried out in ancient time, in the Greek polis and in Rome, from Byzantium to the Imperial China. In fact, without taking into consideration the diplomatic interchanges taking place in the rest of the world (as for example the relations between Great Empires such as the Chinese, the Indian, and the Ottoman one.), we can study the relationship between the Pope and the Byzantine Emperor and later the sovereign Heads of different States. In that time Papal agents, permanently resident in Constantinople, used diplomacy to solve problems and later, in the 8th century, to solve the conflicts 
between the Pope and the Emperor. Diplomacy was born in parallel with the creation of the Political Science Major and doctrine, and it was enhanced by the posthumous publication of the book of Niccolò Machiavelli "Il Principe" in 1532, five years after his death.

According to the Italian perspective Machiavelli must thus be considered one of the most important precursors of the study and analysis of modern diplomacy.

Later, the Italian city-state Milan played a leading role in the development of the art of diplomacy, especially under Francesco Sforza who established permanent Embassies in other city-states of Northern Italy with the introduction of an Ambassador's credentials to the head of state, and even to the king of France in 1455.

At one point, all the most important European powers were exchanging representatives and in 1487 the Spanish King was the first to send a permanent representative (an Ambassador) to the Court of England.

By the late 16th century, permanent missions in Europe became the standard. Many of the conventions of modern diplomacy were established during this period and the Ambassador was the top rank representative, with powers of the Head of State certified in letters of "accreditation".

At that time, Ambassadors were recruited especially from the aristocratic families who had often previous relations with aristocratic and powerful families of the receiving states and knew the language of that state. At the same time, permanent foreign Ministries were established in almost all European states to coordinate Embassies and their staffs.

According to certain authors beginning in the sixteenth century, the term "diplomatic" came to refer to the science of codifying handwriting that was needed to authenticate the validity of diplomas issued by religious authorities (see Halvar Leira, A Conceptual History of Diplomacy, The Sage Handbook of Diplomacy, 2016).

According to others, the origin of the word diplomacy starts from the late 18th century: from French "diplomatie", from diplomatic (diplomatique), on the pattern of aristocracy (aristocratie).

In the early eighteenth century, some model of modern diplomacy gradually spread to Eastern Europe and in particular to Russia.

The entire system was greatly upset by the French Revolution and the subsequent years of conflict, rendering the already established Institutions less recognized. In fact, Napoleon refused to accept the diplomatic immunity, and accused several British diplomats on conspiracy against France and has imprisoned them. Napoleon indeed preferred direct military action over diplomacy.

After Napoleon was defeated, the Congress of Vienna of 1815 established an international system of diplomatic ranking. Important development of different forms of diplomacy are related also with the previous Peace of Westphalia in 1648. From November 1814 to June 1815, five months after Napoleon's first abdication, the Congress of Vienna, marking the triumph of diplomacy. 


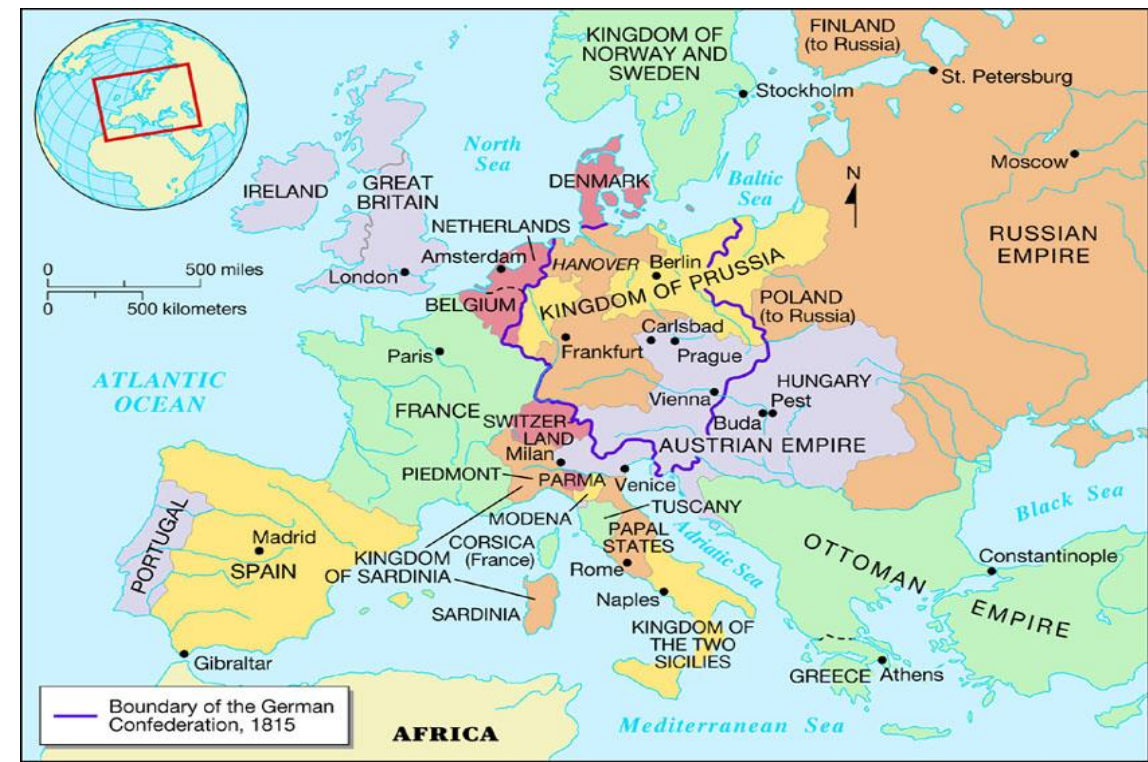

Figure 1: Boundary of the German Confederation, 1815, Elaborated by author from Wikipedia

The ambassadors of European states met to negotiate peace based on the principle of legitimacy, with the aim of restoring sovereign families overruled by Napoleon and guarantee political balance through the division of Europe into spheres of influence: from the borders of France, to the enlargement of Prussia, and the recognition of the Kingdom of Sardinia.

The Congress of Vienna contributed simultaneously to limit the expansion of the Russian Empire on one hand, and that of the Austrian Empire, which chaired the Congress with Klemens von Metternich, on the other.

The real winner of the Congress of Vienna, however, was the French Talleyrand, who, appealing to the principle of the restoration of legitimacy, saved the extension of France's original Kingdom.

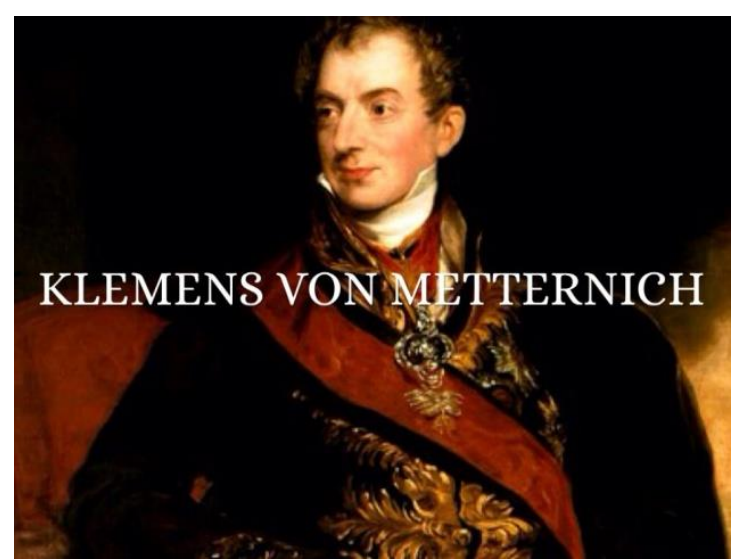

Figure 2: Picture of Klemens Von Metternich, from Wikipedia 
After the British parliamentarian Edward Burke replaced what had been previously called "negotiation by diplomacy" at the end of the 18th century, the subsequent understanding of diplomacy would significantly depart from the original meaning of the term (see Geoff Berridge, Diplomacy: theory and practice, function of diplomacy, NY, Palgrave, 2005).

Of great relevance has also been the Paris Peace Conference, also known as the Versailles Peace Conference, held in 1919 where the Allied victors met, following the end of World War I, to set the peace terms for the defeated Central Powers with the participation of diplomats from more than 32 Countries and nationalities.

The appointment of appropriate diplomatic ranks often became subject of disputes regarding the importance between nations, and these disputes continued for over a century up to the end of the Second World War; the rank of Ambassador was clearly defined starting from the moment in which a transparent and shared presentation of letters of accreditation occurred.

The next Vienna Convention on Diplomatic relations was adopted in April 1961.

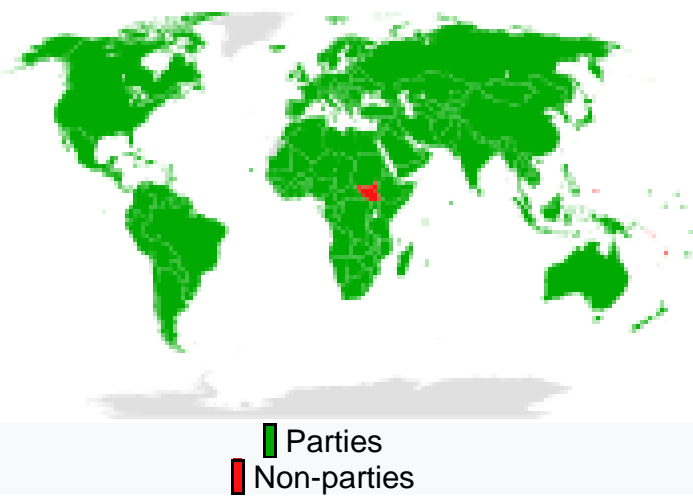

Figure 3: Vienna convention. Elaborated by author from Wikipedia

The parties taking part to the meeting elaborated an international treaty that defined a framework for diplomatic relations among independent Countries and peoples, so there are more than 180 parties to the Convention.

Recalling that all nations have recognized the status of diplomatic agents, much of this convention reproduces existing customary international law and reflects the purposes and principles of the Charter of the United Nations concerning the sovereign equality of States, the maintenance of international peace and security, and the promotion of friendly relations among nations.

In conclusion, the most important international works to regulate the wide field of diplomatic relations and immunities were brought about by the Vienna convention of 1961, then followed by that of 1963 on consular relations; these defined the rules of the game. 


\section{International legal personality}

\subsection{The State}

A nation or territory considered as an organized political community under one government.

The state shall comprise the requirements of 1. Effectiveness; 2. Independence.

The legal effectiveness of a state is in relation with the integration of international law within its state law, through the process by which international agreements become part of a sovereign state. In this case the state includes a treaty by passing domestic legislation that gives effect to the treaty in the national legal system.

A state is considered to be independent and sovereign when its legal force is undermined by its own constitution and not because of the legal order of another state ("superiorem no recognoscens", even absolute and indivisible).

The international legal personality gives the power to conclude agreements. The international subject (state) is uniquely understood and has the power to conclude agreements and express a foreign policy.

The International legal personality is an important aspect of international law, developed through history as a means of international representation for the achievement of a personality.

With personality come privileges as well as responsibilities. Personality has been given to states, corporations, NGOs, international organizations, and individuals.

Rules made by states for states are the foundation of international law that governs states and their relationships. Historically it was considered that states were the only players in international arena and therefore other entities were just under the responsibility of international law.

Diplomacy today involves greater psychological skills and perception than it did in the past. This requires negotiations to approach their tasks from the point of resorting issues of the common interest rather than gain advantage over the other side.

Real world diplomatic negotiations are very different from intellectual debates in a university, where an issue is decided on the basis of the arguments, and negotiators make a deal by splitting the difference.

Though real world diplomacy has traditionally been profoundly influenced by hard power, diplomatic agreements can be occasionally reached among liberal democratic nations due to the interest in higher principles.

The interaction of forces and diplomacy can be explained through a comparison of labour negotiations. If a labour union is not available to strike, then the union is not achieving much because management has unequivocally no incentive to agree to union demands. Likewise, if management is not open to take a strike, then the company will be overridden by the labour union, and management will be forced to agree to any demand the union makes. It is possible to apply the same rule to diplomatic negotiations. 
Even though diplomacy supports rational decision-making processes, it often has to be conducted through irrational acts in order to overcome hostilities amongst parties. However, the advantage gained through diplomatic action could be less than what expected if the latter becomes the cause of an increased hostility from third parties. In modern diplomacy numerous situations are similarly rule-based. When for instance two World Trade Organisation members have trade disputes, it is in the interest of both to limit the damage from affecting other areas by following some agreed-upon rules: in this case the importance of diplomacy is clear.

\subsection{Diplomatic recognition}

Diplomatic recognition in international law is a unilateral political act with domestic and international legal consequences whereby a state acknowledges an act or status of another state or government in control of a state. Only after recognition the new state becomes a holder of rights and international obligations.

We have two typologies of recognition: de facto or de jure. Recognition can be a declaration to that effect by the identifying government, or an act of recognition such as entering into a treaty with the other state.

A vote by a country in the United Nations in support of the membership of another country is an implicit recognition of that country by the voting country, as only states may be members of the UN.

The non-recognition of particular acts of a state does not usually affect the recognition of the state itself. For example, the international rejection of the occupation of a particular territory by a recognised state does not imply non-recognition of the state itself, nor a rejection of a change of government by illegal means.

Political recognition is an act that expresses the will of a state to entertain friendly relationships with another state, and to start a more or less intense cooperation with it.

- Brussels Declaration of 16 December 1991 of the European Community On "Guidelines on the Recognition of New States in Eastern Europe and in the Soviet Union"

- Brussels Declaration of 16 December 1991 of the European Community on Yugoslavia

We have a lot of case studies, among which we can find examples such as that of Crimea, Kosovo, Trans-Dniester (in Moldova, the "Pridnestrovian Moldavian Republic" in Russian Language), Abkhazia, South Ossetia, etc. 


\subsection{Diplomatic protection}

Today states tend to offer their citizens abroad diplomatic and consular protection, depending on whether they act upon their own name or on behalf of a compatriot. Consular protection is far more accessible than diplomatic protection since the conditions necessary to guarantee the latter are much more rigid.

The institution's characteristics:

- the state invokes its own right;

- the state is lost in the person of its citizens, natural or legal person (criterion of nationality);

- the exercise of diplomatic protection presupposes that a State has violated a rule of international law;

- the State can only be activated if its citizens have completed the internal rights of appeal procedural condition.

The detailing rule to pursuing the exercise of diplomatic protection:

- the traditional admitting the use of force (for example the peaceful naval block);

- in 1907 the Second Convention of The Hague Drago-Porter Convention on the Limitation of the Force to Recover Contracts was approved;

- in 2002 the IDC (International Diplomatic Corp) excluded the use of force (for example interventions in favour of its own citizens abroad) was included among the resources for the use of diplomatic protection, constituting an exception to the prohibition of the use of force.

\subsection{Non-interference in domestic affairs}

In international law, the principle of non-interference (or principle of nonintervention) in the domestic affairs of another sovereign state includes, among other prohibitions, that of the threat or use of force against the territorial integrity or political independence of any state.

The principle of non-interference in domestic affairs of States also means that a State should not intervene in a dictatorial way in the internal affairs of other States, as clearly stated in the conventions.

Armed intervention and all other forms of interference or threat, directed against the personality of a state or against its political, economic and cultural structures are against international law.

Intervention, in this case even military, with consent appropriately given by the Government of a State is not precluded. 
Another problem to be taken into account is the situation of emergency. In this case, the importance of non-intervention is related to the international relations that in recent years have been characterised by a growing number of conflicts, thus providing extensive examples regarding the interference by one or more countries in the internal affairs of other countries.

The principle is interpreted in the Resolution UN 2625, 25 October 1970, but also in the final act of the conference carried out in Helsinki by OSCE (Organisation for Security and Cooperation in Europe) on August 1, 1975 and it was signed by 35 States at the Helsinki Summit - stage III of the Helsinki negotiations.

Forming the backbone of the Organization's activities, the Final Act covers several themes:

- non-intervention in internal affairs;

- sovereign equality, respect for the rights inherent in sovereignty;

- refraining from the threat or use of force;

- inviolability of frontiers;

- territorial integrity of States;

- peaceful settlement of disputes;

- respect for human rights and fundamental freedoms (including the freedom of thought, conscience, religion or belief);

- equal rights and self-determination of peoples;

- co-operation among States, and fulfilment in good faith of obligations under international law.

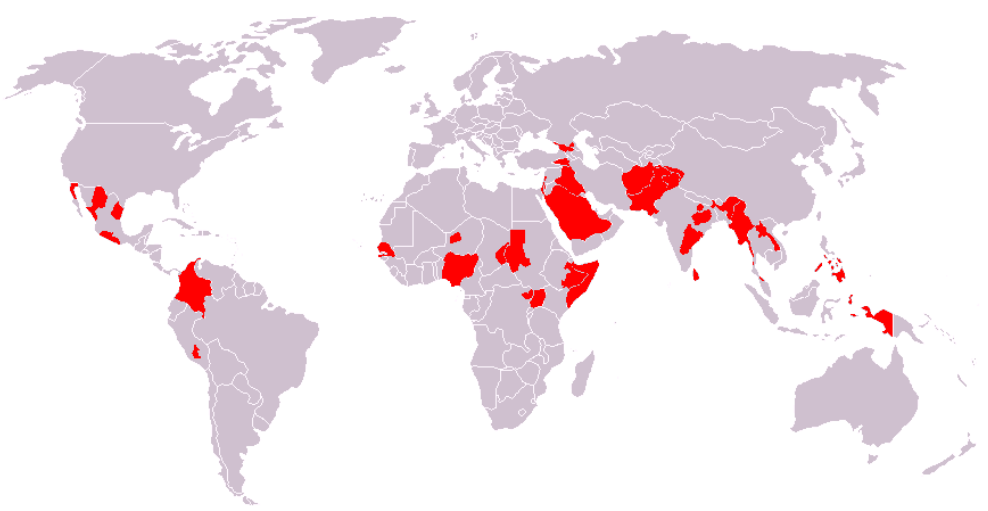

Figure 4: The world conflicts. Elaborated by author from http://contropiano.org/documenti/2017/01/06/la-guerra-mondiale-corso-coinvolti-47-paesi087675

Finally, we must specify that all States must also abstain from organizing, 
supporting, fostering, financing, encouraging or tolerating armed subversive activities or terrorist threats to change through violence the government of the other state, as well as from intervening in the internal struggles of another state.

\section{European union and diplomacy}

Currently, "Ambassadors of the European Union" who are working to third countries and international organizations are known as delegation heads or envoys. Previous to the Lisbon Treaty, the EU was represented abroad by the Ambassador of the country holding the biannual EU presidency, and the European Commission was represented by a "Head of Delegation of the European Commission", member of the diplomatic corps.

Since 2010, the Ambassadors of the European Union are accredited as Extraordinary and Plenipotentiary Ambassadors and are appointed by the President of the European Council and the President of the European Commission, following a proposal by the High Representative of the Union for Foreign Affairs and Security Policy.

They are chosen among candidates coming from the European Union External Action Service (EEAS), the European Commission, the European Council and, today, the 27 Ministries of Foreign Affairs of the Member States of the European Union.

\subsection{Foreign Policy of EU - Strategy}

The Lisbon Treaty included the role of the EU foreign policy high representative and established the European External Action Service.

The implementation of those reforms has delivered some improvements in the way the EU runs its foreign policy.

The treaty ended the system under which the chair of EU foreign ministers' meetings and many of the working groups rotated among member states every six months. The EU's foreign policy needs more continuity.

Where the EU has relationships, EU political functions used to be supported by embassies of the member state holding the rotating presidency. The Lisbon Treaty transferred that responsibility to EU delegations, and the shift has been a success. Thanks to this, the EU has more visibility and a stronger voice around the world.

\subsection{High Representative of the Union for Foreign Affairs and Security Policy}

In terms of substantive politics, the High Representative of the Union for Foreign Affairs and Security Policy cannot be stronger than the Common Foreign and 
Security Policy itself, which means that all still depends on achieving settlement among the EU's 27-member states.

The high representative's central position beyond the Lisbon Treaty foreign policy structures makes this promotion a significant indicator of the EU's level of motivation and ambition.

It will be important to reorganize the commission in a way that allows for better coordination between external policies and allow the Common Foreign and Security Policy to develop the EU's ability to pull all its assets together and act in a coherent and comprehensive fashion.

In any case it is clear how also in the European Union there is foreign policy and diplomacy.

Diplomacy is the effort of maintaining good relations between the governments of different countries, a skill that requires the ability to deal with others without producing immoral feelings. It is also an ethical issue.

The main goals of the European Union Foreign Policy are:

1. defend the EU and its citizens;

2. support human rights, democracy and principles of freedom globally;

3. support the EU's economic growth.

The European Foreign Policy uses a Foreign Aid system, to establish friendly relations abroad by using different means such as economic aids (EU funding) or advice (such as how to install democratic conditions).

Treaties are formal agreements (alliances) between countries that, just like laws, must be followed.

A European Union Association Agreement (Association Agreement) is a treaty between the European Union, its Member States and a non-EU country that creates a framework for co-operation between them.

Areas frequently covered by such agreements include the development of political, trade, social, cultural and security links.

The legal base for the conclusion of the association agreements is provided by art.

217 TFEU (former art. 310 and art. 238 TEC).

\subsection{EU Association Agreements in force}

- African Caribbean and Pacific Group States (2003);

- Albania (2009) Stabilization and Association Agreement;

- Algeria (2005) Euro-Mediterranean Agreement Establishing an Association;

- Bosnia and Herzegovina (2015) Chile (2005) Agreement Establishing an Association/Association Agreement;

- Egypt (2004) Euro-Mediterranean Agreement Establishing an Association;

- Georgia (2016) Agreement Establishing an Association/Association Agreement; 
- Iceland (1994) European Economic Area;

- Israel (2000) Euro-Mediterranean Agreement Establishing an Association;

- Jordan (2002) Euro-Mediterranean Agreement Establishing an Association;

- Kosovo (2016) Stabilization and Association Agreement;

- Lebanon (2006) Euro-Mediterranean Agreement Establishing an Association;

- Liechtenstein (1995) European Economic Area;

- Macedonia (2004) Stabilization and Association Agreement;

- Moldova (2016) Agreement Establishing an Association/Association Agreement;

- Montenegro (2010) Stabilization and Association Agreement;

- Morocco (2000) Euro-Mediterranean Agreement Establishing an Association;

- Norway (1994) European Economic Area;

- Serbia (2013) Stabilization and Association Agreement;

- South Africa (2004);

- Syria (1978) cooperation programs suspended in 2011;

- Tunisia (1998) Euro-Mediterranean Agreement Establishing an Association;

- Turkey (1964) the framework for a Custom Union (1995) Agreement Establishing an Association/Association Agreement;

- Ukraine (2017) Agreement Establishing an Association/Association Agreement;

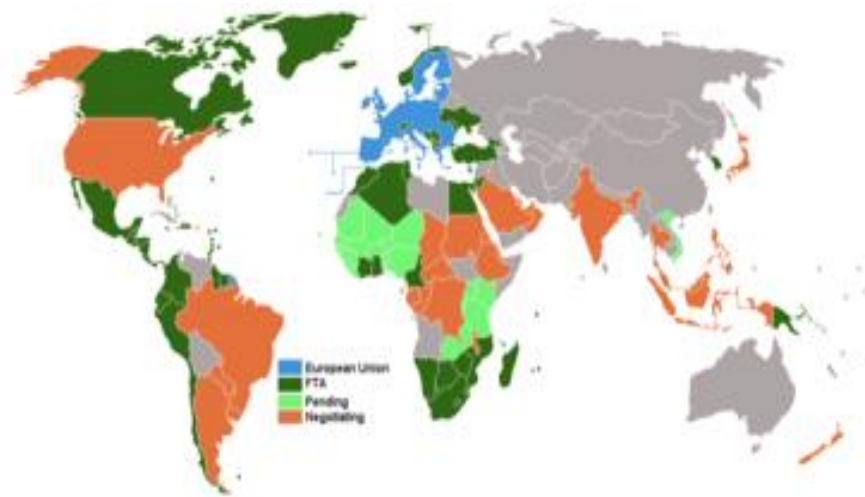

Figure 5: EU Association Agreements in force. Elaborated by author from Wikipedia

\section{European union free-trade agreements}

In force

- Andorra (1991) Customs Union;

- Faroe Islands (autonomous constituent country of the Kingdom of Denmark) (1997) Free Trade Agreement; 
- Mexico (2000) Economic Partnership, Political Coordination and Cooperation Agreement;

- Monaco (1958) Customs Union;

- Palestinian Authority interim (1997) Euro-Mediterranean Agreement Establishing an Association;

- San Marino (2002) Agreement on Cooperation and Customs Union;

- South Korea (2015) Free Trade Agreement;

- Switzerland (1973) Free Trade Agreement;

A free-trade area is the region encompassing a trade bloc where the European Union and other countries have signed a free-trade agreement (FTA).

Such agreements involve cooperation between countries to reduce trade barriers import quotas and tariffs - and to increase trade of goods and services with each other.

Diplomacy is essentially a term that is usually important for International relations between various nations. Diplomacy is the art of negotiations between various countries, but in international relations it forms also the basis of trade.

\subsection{Globalised Diplomacy}

Globalisation is an ongoing process that involves interconnected changes in the economic, cultural, social, and political spheres of society.

Politically, it refers to the development of forms of governance that operate at the global scale, the policies and rules of which are expected to be abided by cooperative nations.

What is new about globalisation and what is relevant to diplomacy depends on our perspective, in fact, since globalisation as a term came to prominence in the 1980s. Although many consider this process a relatively new phenomenon, globalisation has been happening for millennia as changes conditioned by space and time and that contributed to mould global politics.

A consequence of globalisation is that people feel that their lives are shaped by external events and go beyond their control.

Today, a lot of changes are occurring and the international arena is often involved in often involved in permanent crises.

Some large and economically successful countries are seen as today's "emerging powers", joining the high table of the world's major and near major powers:

- IBSA, that is, India, Brazil and South Africa;

- BRICS, consisting of Brazil, Russia, India, China and now South Africa; two of the five are permanent members of the UN Security Council, but only one is a member of G-8;

- Behind these small clusters are other states, such as Egypt, Indonesia, Mexico, and Nigeria that aspire to recognition as emerging powers.

These are all products of the persistent complexity of globalisation. 
Can diplomacy be considered globalised? Given how the effects of globalisation can be observed acting on the complex system of diplomacy, it certainly can be considered globalised.

Indeed, according to some scholars, globalisation emerged at the end of the Cold War with the breaking down of borders and the opening up of systems to greater interdependence, fuelled by the twin forces of technology and economic liberalisation (see NIALL FERGUSON, Empire: The Rise and Demise of the British World Order and the Lessons for Global Power, NY, Basic Books, 2003).

We are currently facing the same changes brought by globalisation that the complex world of diplomacy is facing, which, in an interconnected world, becomes ever more relevant. Diplomacy is a system of regional communication and issue determination in permanent dialogue.

Traditional diplomacy based on traditional borders often disappears to make room for states that, thanks to technology, adopt new forms of diplomacy while trying to maintain a certain coherence with the principles of mutual respect (for more details refer to the "Matrix of Globalised Diplomacy" below (see Kishan Rana, 21 Century Diplomacy. A practitioner's Guide, London, Continuun Books, 2011).

\section{The global diplomacy case}

Over the past few years, the world seems to have suddenly developed an interest in all conflicts and states want to use diplomacy as a tool to have influence in the resolution of said conflicts.

We have a lot of examples of the influence of diplomacy in the global system, such as the case of Iran under Ahmadinejad. But while Americans and Europeans discuss the sanctions to be imposed on Tehran, Israel is growing increasingly worried by the intensification of political and economic relations between the Islamic Republic and several South American countries.

In fact, Iran's strategy would be to develop alternative trade routes in order to balance, at least partially, the restrictions imposed by the West. And this would greatly reduce the impact of the same sanctions on the Ayatollah regime (see Alessandro Figus, $\mathrm{La}$ politica estera dell'Iran tra occidente e crisi nucleare, Eurilink, 2013).

However, this phenomenon would not be ascribable to the actual removal of power of these nations - including Brazil, Venezuela, but especially Argentina - by Israel. Rather, the reasons would be in the will to conduct policies opposed to US interests in the world.

Most of the countries in Latin America are accusing all the last US administrations both democratic and republican - of not being sufficiently interested in their fate.

Therefore, a "third-generation" approach would seem to be the ideal solution to the problem: given the indifference of world economic powers, it is best to opt for mutual solidarity among the weaker nations.

Faced with the approaches between these countries and Iran, the Israeli diplomatic machine immediately set in motion. Given the very idyllic relations, however, in the 
case of Brazil and Venezuela the ascendant from Israel is still extremely weak. But, as far as Argentina is concerned, the issue is different. Relations with Buenos Aires are better than other Latin American countries.

In this sense, Israel could propose to build a bridge to foster the rapprochement between Argentina and the United States. This is the main role of global diplomacy. At this point, everything depends only on one variable: the will of the government led by Cristina Kirchner. Approaching the world superpower by alienating the South American allies, or continuing on the Third World Way by colliding with Washington? This is a non-indifferent strategic dilemma. The consequences of which will be felt, in one way or another, even in the "far" Middle East.

Many of the ongoing issues, even for the actors involved around the world, focus on another example of globalised diplomacy, and that is the issue of the Russian influence in the U.S. Presidential elections.

In fact, the matter revolves around President Donald Trump's eldest son admission that he recently met with a Kremlin-linked lawyer last year after being promised she had "very high-level and sensitive information" that would "incriminate" Hillary Clinton.

Donald Trump Jr. was told in an email by British publicist Rob Goldstone, an intermediary he knew from his father's Miss Universe pageant in Moscow, that the proposal was "part of Russia and its government's support" for his father. U.S. intelligence agencies said that "Putin's goal was to get Trump in the White House,". Trump campaign's digital operation - overseen by Jared Kushner - helped guide Russia's sophisticated voter targeting and fake news attacks on Hillary Clinton.

Everything revolves around communication (email) and technology; it is yet another example of globalised diplomacy.

Globalisation gives the chance to shape the world, which is becoming smaller and smaller, as a world of peace and solidarity. In this case the question is what is the role of diplomacy in a globalized, information-technology led, and telematics age, "the age of communication", where distances have been cancelled by new media in continuous development.

There has been a revolution in communication since 1995. Since then, computers with Internet access and mobile phones became a regular part of the landscape and transformed our lives.

Internet's popularity and the consequent progress of globalisation developed in parallel with diplomatic actions and international relations leading diplomacy to think out of the box, and to adapt to new regulations in globalised times.

The big keyword, especially in European Union is "integration" often processed in the words "standardisation" or "homologation". 


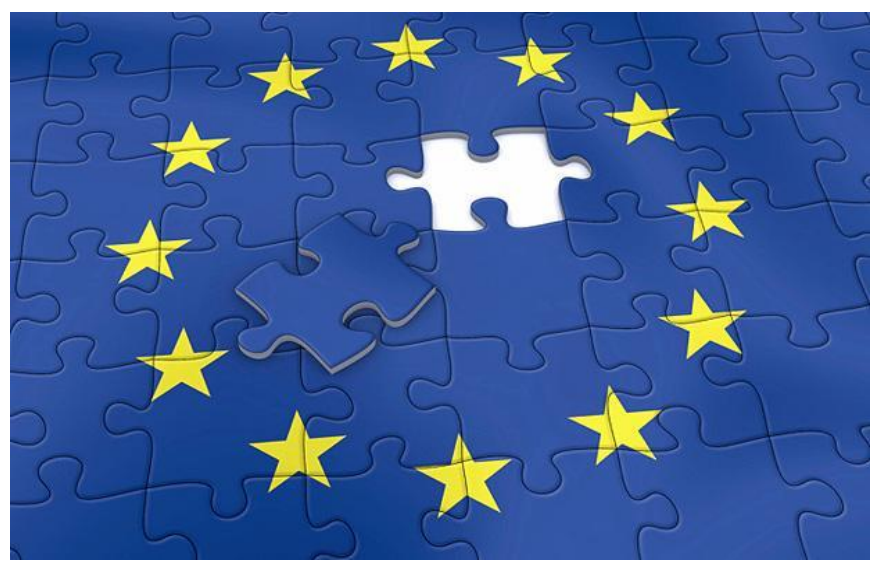

Figure 5: EU integration, elaborated by author from http://www.euro-centre.eu/europeanintegration/

Diplomacy shall comply with all society changes, that is why we can now speak about "globalised diplomacy", a time where the role of the Ministry of Foreign Affairs loses relevance with respect to the traditional standard that has accompanied the idea of diplomacy for centuries.

It is a time of change of foreign relations, because the phenomenon of globalisation is growing and there are new emerging countries and also new actors and new competitors from the world economy, such as large tech companies like Apple, Facebook, etc.

They are stronger than some states. At the same time new competitors are coming from China and Japan, and they are making a grand entrance on the international economic stage, compelling the world market to confront the challenge of fresh competition based on innovation. It is necessary, thus, for diplomacy to evolve. 


\section{Founding of the UN in 1945}

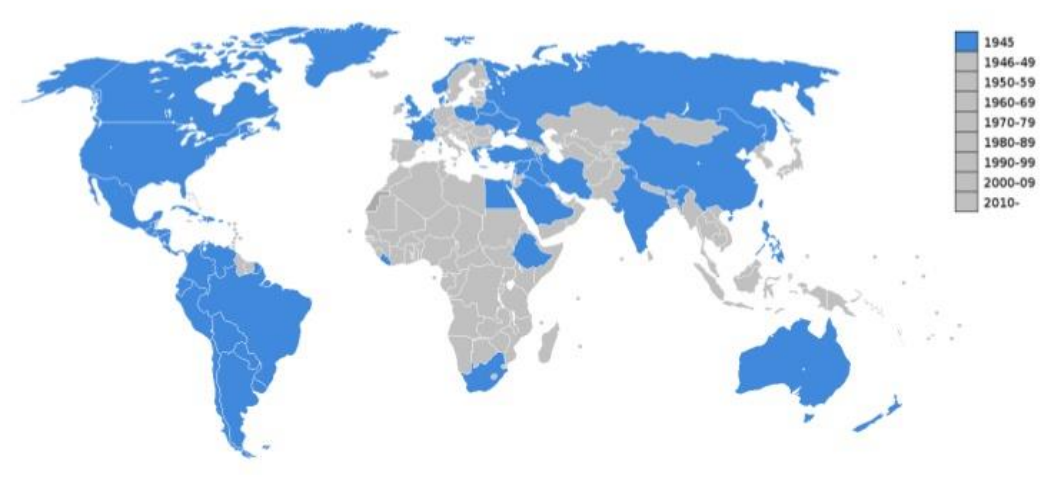

United Nations was founded by 51 states in 1945.

Figure 6: UN members in 1945, elaborated by author from UN website

Following the nineteenth century conception, there are the sovereign states, that are "superiorem non recognoscens".

A sovereign state cannot accept orders from anyone.

According to the classical view of international law, the sovereign state, in order to accept the imposition of a new order, must be defeated in war. Nowadays, sovereign states are still fundamental but not exclusive.

There are other non-sovereign subjects that certainly do foreign policy, such as "international organizations" (governmental and non-governmental organizations), large industrial groups, religious confessions (not through theocratic states but through religious leaders), even large criminal groups. 


\section{The conflicts map by UCDP: an example}

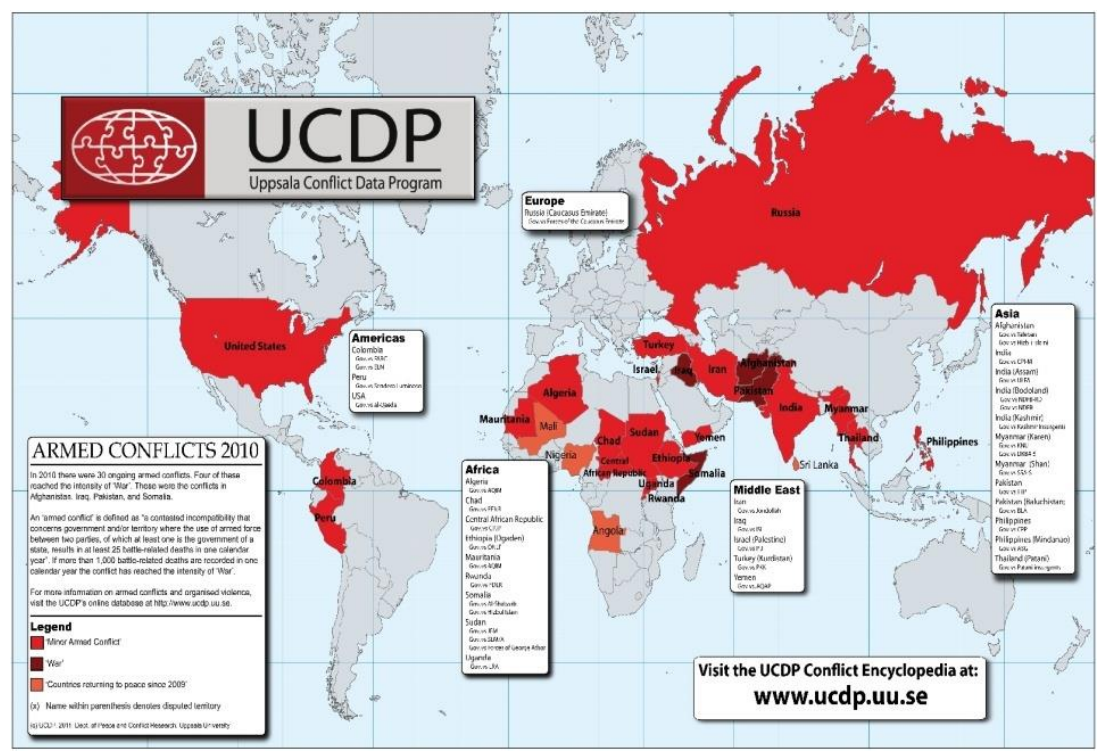

Figure 7: World conflicts map, elaborated by author from UCDP website

We aim to foster an understanding of two central concerns of International Relations - the recurrence of conflict and the role of diplomacy in relations between international political actors.

The study of crucial case studies in contemporary conflict and diplomacy is extremely important. It is crucial today in Diplomatic Sciences to analyse the actors, structures and processes that shape foreign and security policy-making, and at the same time to explore the changing character of modern conflict, the role of conflict resolution processes and the nature of diplomatic relations between major powers.

An example is the conflict between the UK and Argentina in the 1980s. The dispute between Argentina and Great Britain over the Falkland/Malvinas Islands led, in fact, to the only major war between two Western countries since World War II. It is an interesting case for the study of preventive diplomacy and conflict management, as it involves a cross-section of international relations, it was an example of conflict as well as a failure of diplomacy.

The conflict involved:

1. a major power, Great Britain;

2. the active participation of the US, first as a mediator and then as an ally to one of the parties;

3. a subcontinental power, albeit a "minor" player in a broader context, Argentina;

4. a global intergovernmental organization, the United Nations; 
5. a regional intergovernmental organization, the Organization of American States (OAS).

For deeper insight into this case, please refer to:

Sinagra Augusto, Controversie territoriali tra Stati e decolonizzazione. Il contenzioso angloargentino per le isole Falkland-Malvinas, (Collana Univ. Studi Genova, Fac. Scienze Politiche), Giuffrè, Milano, 1983, pp. XII-168.

The Falklands/Malvinas territory, situated about 500 miles northeast of Cape Horn and 300 miles east of the Argentine coastline, comprehends two large islands, East and West Falkland (Soledad and Gran Malvina, according to the Argentine denomination) and also includes around 776 smaller islands. The main islands are about 300 miles (483 kilometres) east of South America's southern Patagonian coast, at a latitude of about $52 \mathrm{~S}$. The archipelago, with an area of 4,700 square miles (12,000 square kilometres), comprises East Falkland and West Falkland as a British overseas territory. The Islands have internal self-governance, and the United Kingdom takes responsibility for their defence and foreign affairs.

The population of the Malvinas is today around 3.000 people, Argentina formally brought the dispute over sovereignty to the attention of the UN, in the context of decolonization, in 1965.

The conflict was a major episode in the protracted confrontation over the territories' sovereignty. Argentina asserted (and maintains) that the islands are Argentinian territory, and the Argentinian government thus characterised its military action as the reclamation of its own territory. The British government regarded the action as an invasion of a territory that had been a Crown colony since 1841 . 

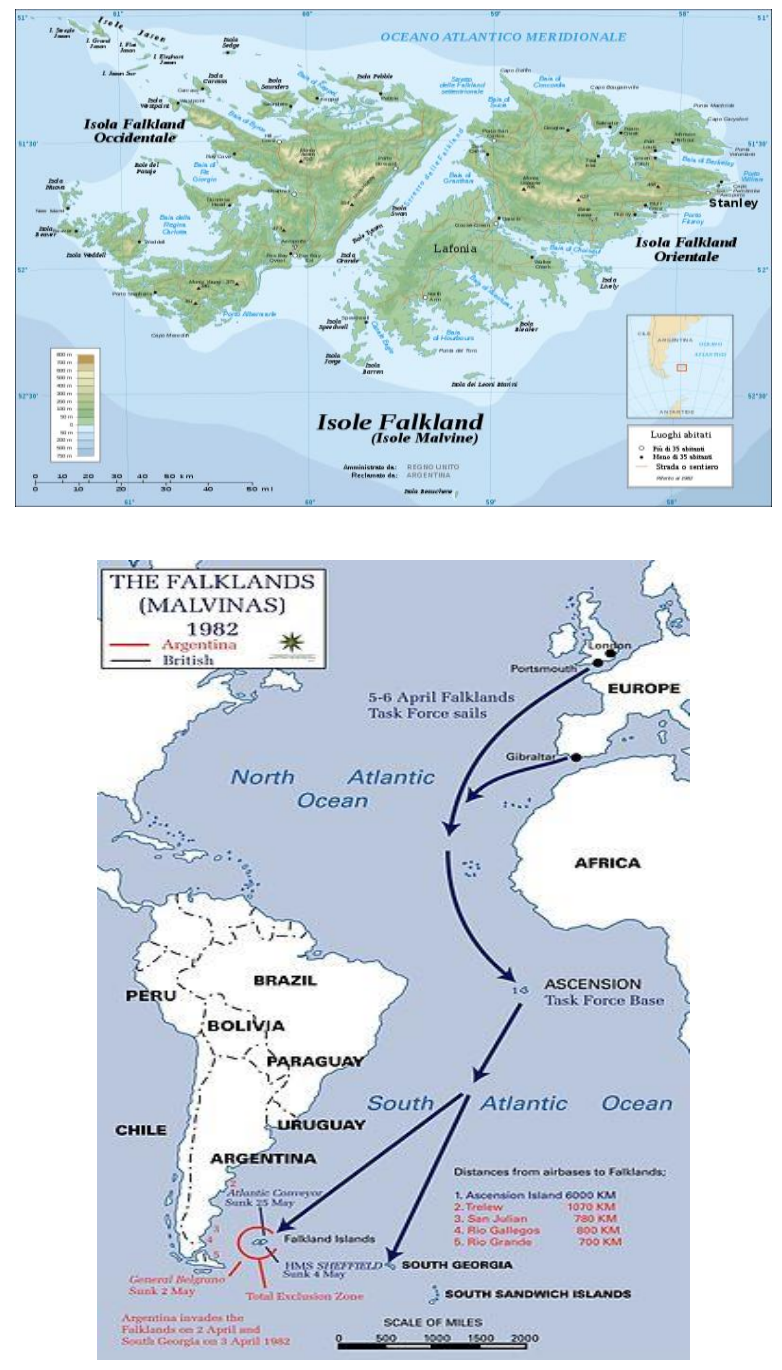

Figure 8: Island Malvinas war, elaborated by author from Britannica.com website

Falkland Islanders (Malvinas), who have inhabited the islands since the early 19th century, are predominantly descendants of British settlers and favour British sovereignty.

Neither State officially declared war, but both governments declared the Islands a war zone and officially accepted that a state of war existed between them and hostilities were almost exclusively limited to the territories under dispute in that specific area.

The conflict has had a strong effect in both countries. Nationalistic sentiment ran high in Argentina, as well as large protests against the ruling military government, 
that was overthrown. In the UK, the Conservative government of Margaret Thatcher, reinforced by the successful outcome, was re-elected the following year. The cultural and political effects of the conflict have affected Britain less than Argentina, where today the conflict still remains a common theme for discussion. Diplomatic relations between the United Kingdom and Argentina were restored in 1989, when a joint statement was issued by the government.

In 1994, Argentina's claim to the territories was added to its constitution.

\section{List of important international organisations and their headquarters}

\begin{tabular}{|c|c|c|c|}
\hline & $\begin{array}{l}\text { International } \\
\text { organisation }\end{array}$ & Acronym & $\begin{array}{l}\text { Head office / } \\
\text { Location }\end{array}$ \\
\hline 1 & $\begin{array}{l}\text { Africa Finance } \\
\text { Corporation }\end{array}$ & $\mathrm{AFC}$ & Lagos \\
\hline 2 & $\begin{array}{c}\text { African } \\
\text { Development Bank }\end{array}$ & AfDB & Abidjan \\
\hline 3 & $\begin{array}{c}\text { African } \\
\text { Development Bank } \\
\text { Group } \\
\end{array}$ & AfDB & Abidjan \\
\hline 4 & $\begin{array}{c}\text { African } \\
\text { Development Fund }\end{array}$ & AfDF & Abidjan \\
\hline 5 & $\begin{array}{l}\text { African Export- } \\
\text { Import Bank }\end{array}$ & Afreximbank & Cairo \\
\hline 6 & African Union & $\mathrm{AU}$ & Addis Ababa \\
\hline 7 & $\begin{array}{c}\text { Agency for the } \\
\text { Cooperation of } \\
\text { Energy Regulators }\end{array}$ & ACER & Ljubljana \\
\hline 8 & $\begin{array}{l}\text { Andean } \\
\text { Development } \\
\text { Corporation }\end{array}$ & CAF & Caracas \\
\hline 9 & $\begin{array}{c}\text { Arab Bank for } \\
\text { Economic } \\
\text { Development in } \\
\text { Africa }\end{array}$ & BADEA & Khartoum \\
\hline 10 & $\begin{array}{l}\text { Arab Fund for } \\
\text { Economic and } \\
\text { Social } \\
\text { Development }\end{array}$ & AFESD & Kuwait \\
\hline 11 & $\begin{array}{l}\text { Arab Monetary } \\
\text { Fund }\end{array}$ & $\mathrm{AMF}$ & Abu Dhabi \\
\hline 12 & $\begin{array}{c}\text { Asian Clearing } \\
\text { Union }\end{array}$ & $\mathrm{ACU}$ & Tehran \\
\hline 13 & $\begin{array}{c}\text { Asian } \\
\text { Development Bank }\end{array}$ & $\mathrm{ADB}$ & Manila \\
\hline 14 & $\begin{array}{c}\text { Asian } \\
\text { Development Fund }\end{array}$ & AsDF & Manila \\
\hline
\end{tabular}




\begin{tabular}{|c|c|c|c|}
\hline 15 & $\begin{array}{c}\text { Association of } \\
\text { Southeast Asian } \\
\text { Nations }\end{array}$ & ASEAN & Jakarta \\
\hline 16 & $\begin{array}{c}\text { Bank for } \\
\text { International } \\
\text { Settlements }\end{array}$ & BIS & Basel \\
\hline 17 & $\begin{array}{c}\text { Banque des Etats de } \\
\text { l'Afrique Centrale }\end{array}$ & BEAC & $\begin{array}{c}\text { Yaoundé } \\
\text { (Cameroon) }\end{array}$ \\
\hline 18 & $\begin{array}{c}\text { Black Sea Trade } \\
\text { and Development } \\
\text { Bank }\end{array}$ & BSTDB & Thessaloniki \\
\hline 19 & $\begin{array}{l}\text { Body of European } \\
\text { Regulators for } \\
\text { Electronic } \\
\text { Communications }\end{array}$ & BEREC & Riga \\
\hline 20 & $\begin{array}{c}\text { Caribbean } \\
\text { Community and } \\
\text { Common Market }\end{array}$ & CARICOM & $\begin{array}{c}\text { Georgetown } \\
\text { (Guyana) }\end{array}$ \\
\hline 21 & $\begin{array}{c}\text { Caribbean } \\
\text { Development Bank }\end{array}$ & $\mathrm{CDB}$ & $\begin{array}{l}\text { St Michael } \\
\text { (Barbados) }\end{array}$ \\
\hline 22 & $\begin{array}{c}\text { Central African } \\
\text { States } \\
\text { Development Bank }\end{array}$ & CASDB & Brazzaville \\
\hline 23 & $\begin{array}{c}\text { Central American } \\
\text { Bank for Economic } \\
\text { Integration } \\
\end{array}$ & CABEI & Tegucigalpa \\
\hline 24 & $\begin{array}{l}\text { Central American } \\
\text { Common Market }\end{array}$ & CACM & Guatemala City \\
\hline 25 & Colombo Plan & - & Colombo \\
\hline 26 & $\begin{array}{l}\text { Committee of } \\
\text { Regions }\end{array}$ & CoR & Brussels \\
\hline 27 & $\begin{array}{l}\text { Community Plant } \\
\text { Variety Office }\end{array}$ & $\mathrm{CPVO}$ & Angers \\
\hline 28 & $\begin{array}{c}\text { Computer } \\
\text { Emergency } \\
\text { Response Team }\end{array}$ & CERT & Brussels \\
\hline 29 & Council of Europe & $\mathrm{CE}$ & Strasbourg \\
\hline 30 & $\begin{array}{l}\text { Council of Europe } \\
\text { Development Bank }\end{array}$ & CEB & Paris \\
\hline 31 & $\begin{array}{c}\text { Council of the } \\
\text { European Union }\end{array}$ & CEU & Brussels \\
\hline 32 & $\begin{array}{c}\text { Court of Justice of } \\
\text { the European } \\
\text { Union }\end{array}$ & CJEU & Luxembourg \\
\hline 33 & $\begin{array}{c}\text { East African } \\
\text { Development Bank }\end{array}$ & EADB & Kampala \\
\hline 34 & $\begin{array}{l}\text { Eastern Caribbean } \\
\text { Central Bank }\end{array}$ & ECCB & $\begin{array}{l}\text { St.Kitts (West } \\
\text { Indies) }\end{array}$ \\
\hline
\end{tabular}




\begin{tabular}{|c|c|c|c|}
\hline 35 & $\begin{array}{c}\text { Economic and } \\
\text { Social Committee }\end{array}$ & ESC & Brussels \\
\hline 36 & $\begin{array}{c}\text { Economic } \\
\text { Community of } \\
\text { West African States }\end{array}$ & ECOWAS & Abuja \\
\hline 37 & $\begin{array}{c}\text { ECOWAS Bank } \\
\text { for Investment and } \\
\text { Development }\end{array}$ & EBID & Lomé (Togo) \\
\hline 38 & $\begin{array}{c}\text { EU-Africa } \\
\text { Infrastructure Trust } \\
\text { Fund } \\
\end{array}$ & EU-AITF & Luxembourg \\
\hline 39 & \begin{tabular}{|c|} 
Eurasian \\
Development Bank
\end{tabular} & EDB & $\begin{array}{c}\text { Almaty } \\
\text { (Kazakhstan) }\end{array}$ \\
\hline 40 & $\begin{array}{c}\text { European Agency } \\
\text { for Safety and } \\
\text { Health at Work } \\
\end{array}$ & EU-OSHA & Bilbao \\
\hline 41 & $\begin{array}{l}\text { European Agency } \\
\text { for the } \\
\text { Management of } \\
\text { Operational } \\
\text { Cooperation at the } \\
\text { External Borders }\end{array}$ & FRONTEX & Warsaw \\
\hline 42 & $\begin{array}{l}\text { European Agency } \\
\text { for the operational } \\
\text { management of } \\
\text { large-scale IT } \\
\text { systems in the area } \\
\text { of freedom, } \\
\text { security and justice }\end{array}$ & EU-LISA & Tallinn \\
\hline 43 & $\begin{array}{l}\text { European Asylum } \\
\text { Support Office }\end{array}$ & EASO & Valletta \\
\hline 44 & \begin{tabular}{|c|} 
European Atomic \\
Energy Community
\end{tabular} & Euratom & Brussels \\
\hline 45 & $\begin{array}{c}\text { European Aviation } \\
\text { Safety Agency }\end{array}$ & EASA & Cologne \\
\hline 46 & $\begin{array}{c}\text { European Bank for } \\
\text { Reconstruction and } \\
\text { Development } \\
\end{array}$ & EBRD & London \\
\hline 47 & $\begin{array}{c}\text { European Banking } \\
\text { Authority }\end{array}$ & $\mathrm{EBA}$ & London \\
\hline 48 & $\begin{array}{c}\text { European } \\
\text { Broadcasting } \\
\text { Union } \\
\end{array}$ & $\mathrm{EBU}$ & Geneva \\
\hline 49 & $\begin{array}{c}\text { European Central } \\
\text { Bank }\end{array}$ & $\mathrm{ECB}$ & Frankfurt \\
\hline 50 & $\begin{array}{l}\text { European Centre } \\
\text { for Disease } \\
\text { Prevention and } \\
\text { Control }\end{array}$ & ECDC & Solna \\
\hline
\end{tabular}




\begin{tabular}{|c|c|c|c|}
\hline 51 & $\begin{array}{l}\text { European Centre } \\
\text { for Medium-Range } \\
\text { Weather Forecasts }\end{array}$ & ECMWF & Reading (UK) \\
\hline 52 & $\begin{array}{c}\text { European Centre } \\
\text { for the } \\
\text { Development of } \\
\text { Vocational Training }\end{array}$ & CEDEFOP & Thessaloniki \\
\hline 53 & $\begin{array}{c}\text { European } \\
\text { Chemicals Agency }\end{array}$ & ECHA & Helsinki \\
\hline 54 & $\begin{array}{l}\text { European } \\
\text { Commission }\end{array}$ & $\mathrm{EC}$ & Brussels \\
\hline 55 & $\begin{array}{c}\text { European } \\
\text { Community of } \\
\text { Steel and Coal } \\
\end{array}$ & ECSC & Luxembourg \\
\hline 56 & $\begin{array}{c}\text { European } \\
\text { Company for the } \\
\text { Financing of } \\
\text { Railroad Rolling } \\
\text { Stock }\end{array}$ & EUROFIMA & Basel \\
\hline 57 & European Council & Council & Brussels \\
\hline 58 & $\begin{array}{l}\text { European Court } \\
\text { of Auditors }\end{array}$ & ECA & Luxembourg \\
\hline 59 & $\begin{array}{c}\text { European Data } \\
\text { Protection } \\
\text { Supervisor } \\
\end{array}$ & EDPS & Brussels \\
\hline 60 & $\begin{array}{c}\text { European Defence } \\
\text { Agency }\end{array}$ & EDA & Brussels \\
\hline 61 & \begin{tabular}{|c|} 
European \\
Development Fund
\end{tabular} & EDF & Brussels \\
\hline 62 & $\begin{array}{c}\text { European } \\
\text { Environment } \\
\text { Agency } \\
\end{array}$ & EEA & Copenhagen \\
\hline 63 & $\begin{array}{c}\text { European External } \\
\text { Action Service }\end{array}$ & EEAS & Brussels \\
\hline 64 & $\begin{array}{c}\text { European Fisheries } \\
\text { Control Agency }\end{array}$ & EFCA & Vigo \\
\hline 65 & $\begin{array}{l}\text { European Food } \\
\text { Safety Authority }\end{array}$ & EFSA & Parma \\
\hline 66 & \begin{tabular}{|c|} 
European \\
Foundation for the \\
Improvement of \\
Living and \\
Working \\
Conditions \\
\end{tabular} & EUROFOUND & Dublin \\
\hline 67 & $\begin{array}{c}\text { European Free } \\
\text { Trade Association }\end{array}$ & EFTA & Geneva \\
\hline 68 & $\begin{array}{c}\text { European GNSS } \\
\text { Agency }\end{array}$ & GSA & Prague \\
\hline
\end{tabular}




\begin{tabular}{|c|c|c|c|}
\hline 69 & \begin{tabular}{|c|} 
European Institute \\
for Gender \\
Equality \\
\end{tabular} & EIGE & Vilnius \\
\hline 70 & $\begin{array}{c}\text { European Institute } \\
\text { of Innovation and } \\
\text { Technology }\end{array}$ & EIT & Budapest \\
\hline 71 & $\begin{array}{c}\text { European } \\
\text { Insurance and } \\
\text { Occupational } \\
\text { Pensions Authority }\end{array}$ & EIOPA & Frankfurt \\
\hline 72 & $\begin{array}{c}\text { European } \\
\text { Investment Bank }\end{array}$ & EIB & Luxembourg \\
\hline 73 & $\begin{array}{c}\text { European } \\
\text { Investment Fund }\end{array}$ & EIF & Luxembourg \\
\hline 74 & $\begin{array}{c}\text { European Maritime } \\
\text { Safety Agency }\end{array}$ & EMSA & Lisbon \\
\hline 75 & $\begin{array}{c}\text { European } \\
\text { Medicines Agency }\end{array}$ & EMA & London \\
\hline 76 & $\begin{array}{c}\text { European } \\
\text { Molecular Biology } \\
\text { Laboratory } \\
\end{array}$ & EMBL & Grenoble \\
\hline 77 & $\begin{array}{c}\text { European } \\
\text { Monitoring Centre } \\
\text { for Drugs and } \\
\text { Drug Addiction }\end{array}$ & EMCDDA & Lisbon \\
\hline 78 & $\begin{array}{c}\text { European Network } \\
\text { and Information } \\
\text { Security Agency } \\
\end{array}$ & ENISA & Heraklion \\
\hline 79 & $\begin{array}{c}\text { European } \\
\text { Ombudsman }\end{array}$ & Ombudsman & Strasbourg \\
\hline 80 & $\begin{array}{c}\text { European } \\
\text { Organisation for } \\
\text { the Exploitation of } \\
\text { Meteorological } \\
\text { Satellites } \\
\end{array}$ & EUMETSAT & $\begin{array}{l}\text { Darmstadt } \\
\text { (Germany) }\end{array}$ \\
\hline 81 & $\begin{array}{c}\text { European } \\
\text { Organisation for } \\
\text { the Safety of Air } \\
\text { Navigation }\end{array}$ & EUROCONTROL & Brussels \\
\hline 82 & $\begin{array}{c}\text { European } \\
\text { Organization for } \\
\text { Nuclear Research }\end{array}$ & CERN & Geneva \\
\hline 83 & $\begin{array}{l}\text { European } \\
\text { Parliament }\end{array}$ & EP & Brussels/Strasbourg \\
\hline 84 & $\begin{array}{c}\text { European Patent } \\
\text { Office }\end{array}$ & EPO & Munich \\
\hline 85 & $\begin{array}{c}\text { European } \\
\text { Personnel Selection } \\
\text { Office }\end{array}$ & EPSO & Brussels \\
\hline
\end{tabular}




\begin{tabular}{|c|c|c|c|}
\hline 86 & $\begin{array}{c}\text { European Police } \\
\text { College }\end{array}$ & CEPOL & Budapest \\
\hline 87 & $\begin{array}{c}\text { European Police } \\
\text { Office }\end{array}$ & EUROPOL & The Hague \\
\hline 88 & $\begin{array}{c}\text { European Public } \\
\text { Prosecutor's Office }\end{array}$ & ЕРPO & To be established \\
\hline 89 & $\begin{array}{c}\text { European } \\
\text { Railway Agency }\end{array}$ & ERA & Valenciennes \\
\hline 90 & $\begin{array}{l}\text { European School } \\
\text { of Administration }\end{array}$ & EUSA & Brussels \\
\hline 91 & $\begin{array}{c}\text { European } \\
\text { Securities and } \\
\text { Markets Authority }\end{array}$ & ESMA & Paris \\
\hline 92 & $\begin{array}{c}\text { European Southern } \\
\text { Observatory }\end{array}$ & $\mathrm{ESO}$ & Munich \\
\hline 93 & $\begin{array}{c}\text { European Space } \\
\text { Agency }\end{array}$ & ESA & Paris \\
\hline 94 & $\begin{array}{c}\text { European Stability } \\
\text { Mechanism }\end{array}$ & ESM & Luxembourg \\
\hline 95 & $\begin{array}{c}\text { European Training } \\
\text { Foundation }\end{array}$ & ETF & Turin \\
\hline 96 & $\begin{array}{c}\text { European Union } \\
\text { Agency for } \\
\text { Fundamental } \\
\text { Rights } \\
\end{array}$ & FRA & Vienna \\
\hline 97 & $\begin{array}{l}\text { European Union } \\
\text { Institute for } \\
\text { Security Studies }\end{array}$ & EUISS & Paris \\
\hline 98 & $\begin{array}{l}\text { European Union } \\
\text { Intellectual } \\
\text { Property Office }\end{array}$ & EUIPO & Alicante \\
\hline 99 & $\begin{array}{l}\text { European Union } \\
\text { Satellite Centre }\end{array}$ & SATCEN & Madrid \\
\hline 100 & $\begin{array}{l}\text { Facility for Euro- } \\
\text { Mediterranean } \\
\text { Investment and } \\
\text { Partnership }\end{array}$ & FEMIP & Luxembourg \\
\hline 101 & $\begin{array}{c}\text { Fonds Belgo- } \\
\text { Congolais } \\
\text { D'Amortissement } \\
\text { et de Gestion }\end{array}$ & - & Brussels \\
\hline 102 & $\begin{array}{c}\text { Food and } \\
\text { Agricultural } \\
\text { Organisation }\end{array}$ & FAO & Rome \\
\hline 103 & $\begin{array}{c}\text { Foreign Trade } \\
\text { Bank of Latin } \\
\text { America } \\
\end{array}$ & Bladex & Panama \\
\hline 104 & Fusion for Energy & F4E & Barcelona \\
\hline
\end{tabular}




\begin{tabular}{|c|c|c|c|}
\hline 105 & $\begin{array}{c}\text { Inter-American } \\
\text { Development Bank }\end{array}$ & IADB & Washington \\
\hline 106 & $\begin{array}{l}\text { Inter-American } \\
\text { Investment } \\
\text { Corporation }\end{array}$ & IIC & Washington \\
\hline 107 & $\begin{array}{l}\text { Intergovernmental } \\
\text { Council of Copper } \\
\text { Exporting } \\
\text { Countries }\end{array}$ & CIPEC & Paris \\
\hline 108 & $\begin{array}{c}\text { International } \\
\text { Atomic Energy } \\
\text { Agency }\end{array}$ & IAEA & Vienna \\
\hline 109 & $\begin{array}{c}\text { International Bank } \\
\text { for Economic } \\
\text { Cooperation }\end{array}$ & IBEC & Moscow \\
\hline 110 & $\begin{array}{c}\text { International Bank } \\
\text { for Reconstruction } \\
\text { and Development - } \\
\text { WB Group }\end{array}$ & IBRD & Washington \\
\hline 111 & $\begin{array}{l}\text { International } \\
\text { Centre for } \\
\text { Settlement of } \\
\text { Investment } \\
\text { Disputes - WB } \\
\text { Group }\end{array}$ & ICSID & Washington \\
\hline 112 & $\begin{array}{c}\text { International Civil } \\
\text { Aviation } \\
\text { Organisation }\end{array}$ & $\mathrm{ICAO}$ & Montreal \\
\hline 113 & $\begin{array}{c}\text { International Cocoa } \\
\text { Organisation }\end{array}$ & ICCO & London \\
\hline 114 & $\begin{array}{l}\text { International } \\
\text { Coffee } \\
\text { Organisation }\end{array}$ & $\mathrm{ICO}$ & London \\
\hline 115 & $\begin{array}{l}\text { International } \\
\text { Committee of the } \\
\text { Red Cross }\end{array}$ & ICRC & Geneva \\
\hline 116 & $\begin{array}{c}\text { International } \\
\text { Copper Study } \\
\text { Group }\end{array}$ & ICSG & Lisbon \\
\hline 117 & $\begin{array}{c}\text { International } \\
\text { Cotton Advisory } \\
\text { Committee }\end{array}$ & ICAC & Washington \\
\hline 118 & $\begin{array}{c}\text { International } \\
\text { Development } \\
\text { Association - WG } \\
\text { Group }\end{array}$ & IDA & Washington \\
\hline 119 & $\begin{array}{c}\text { International } \\
\text { Finance } \\
\text { Corporation - WG } \\
\text { Group }\end{array}$ & IFC & Washington \\
\hline
\end{tabular}




\begin{tabular}{|c|c|c|c|}
\hline 120 & $\begin{array}{c}\text { International } \\
\text { Finance Facility for } \\
\text { Immunisation }\end{array}$ & IFFIm & London \\
\hline 121 & $\begin{array}{c}\text { International Fund } \\
\text { for Agricultural } \\
\text { Development }\end{array}$ & IFAD & Rome \\
\hline 122 & $\begin{array}{l}\text { International } \\
\text { Grains Council }\end{array}$ & IGC & London \\
\hline 123 & $\begin{array}{c}\text { International } \\
\text { Investment Bank }\end{array}$ & IIB & Moscow \\
\hline 124 & $\begin{array}{c}\text { International Jute } \\
\text { Study Group }\end{array}$ & IJSG & Dhaka \\
\hline 125 & $\begin{array}{c}\text { International } \\
\text { Labour } \\
\text { Organisation } \\
\end{array}$ & ILO & Geneva \\
\hline 126 & $\begin{array}{c}\text { International Lead } \\
\text { and Zinc Study } \\
\text { Group }\end{array}$ & ILZSG & Lisbon \\
\hline 127 & $\begin{array}{c}\text { International } \\
\text { Maritime } \\
\text { Organisation }\end{array}$ & $\mathrm{IMO}$ & London \\
\hline 128 & $\begin{array}{c}\text { International } \\
\text { Maritime Satellite } \\
\text { Organisation }\end{array}$ & INMARSAT & London \\
\hline 129 & $\begin{array}{c}\text { International } \\
\text { Monetary Fund }\end{array}$ & IMF & Washington \\
\hline 130 & $\begin{array}{c}\text { International Olive } \\
\text { Oil Council } \\
\end{array}$ & IOOC & Madrid \\
\hline 131 & $\begin{array}{l}\text { International } \\
\text { Organisation for } \\
\text { Migration }\end{array}$ & IOM & Geneva \\
\hline 132 & $\begin{array}{c}\text { International } \\
\text { Rubber Study } \\
\text { Group }\end{array}$ & IRSG & London \\
\hline 133 & $\begin{array}{c}\text { International Sugar } \\
\text { Organization }\end{array}$ & ISO & London \\
\hline 134 & $\begin{array}{c}\text { International } \\
\text { Telecommunication } \\
\text { Union }\end{array}$ & ITU & Geneva \\
\hline
\end{tabular}




\begin{tabular}{|c|c|c|c|}
\hline 135 & $\begin{array}{c}\text { International Union } \\
\text { of Credit and } \\
\text { Investment } \\
\text { Insurers } \\
\end{array}$ & Berne Union & London \\
\hline 136 & $\begin{array}{c}\text { Islamic } \\
\text { Development Bank }\end{array}$ & IDB & Jeddah \\
\hline 137 & $\begin{array}{c}\text { Joint Committee of } \\
\text { the European } \\
\begin{array}{c}\text { Supervisory } \\
\text { Authorities }\end{array} \\
\end{array}$ & - & London \\
\hline 138 & $\begin{array}{l}\text { Latin American and } \\
\text { the Caribbean } \\
\text { Economic System }\end{array}$ & SELA & Caracas \\
\hline 139 & $\begin{array}{l}\text { Latin American } \\
\text { Association of } \\
\text { Development } \\
\text { Financing } \\
\text { Institutions }\end{array}$ & ALIDE & Lima \\
\hline 140 & $\begin{array}{c}\text { Latin American } \\
\text { Energy } \\
\text { Organization } \\
\end{array}$ & OLADE & Quito \\
\hline 141 & $\begin{array}{l}\text { Latin American } \\
\text { Integration } \\
\text { Association }\end{array}$ & LAIA & Montevideo \\
\hline 142 & $\begin{array}{l}\text { Latin American } \\
\text { Reserve Fund }\end{array}$ & LARF & Bogotá \\
\hline 143 & $\begin{array}{c}\text { League of Arab } \\
\text { States }\end{array}$ & LAS & Cairo \\
\hline 144 & \begin{tabular}{|c|} 
Multilateral \\
Investment \\
Guarantee Agency - \\
WB Group \\
\end{tabular} & MIGA & Washington \\
\hline 145 & $\begin{array}{c}\text { Neighbourhood } \\
\text { Investment Facility }\end{array}$ & NIF & Rome \\
\hline 146 & $\begin{array}{c}\text { Nordic Investment } \\
\text { Bank }\end{array}$ & NIB & Helsinki \\
\hline 147 & $\begin{array}{l}\text { North Atlantic } \\
\text { Treaty } \\
\text { Organisation } \\
\end{array}$ & NATO & Brussels \\
\hline 148 & $\begin{array}{l}\text { OPEC Fund for } \\
\text { International } \\
\text { Development }\end{array}$ & OFID & Vienna \\
\hline 149 & $\begin{array}{l}\text { Organisation for } \\
\text { Economic Co- } \\
\text { operation and } \\
\text { Development }\end{array}$ & OECD & Paris \\
\hline 150 & $\begin{array}{c}\text { Organisation of } \\
\text { Eastern Caribbean } \\
\text { States } \\
\end{array}$ & OECS & Castries (St Lucia) \\
\hline 151 & $\begin{array}{l}\text { Organisation of } \\
\text { American States }\end{array}$ & OAS & Washington \\
\hline
\end{tabular}




\begin{tabular}{|c|c|c|c|}
\hline 152 & $\begin{array}{c}\text { Organization of } \\
\text { Arab Petroleum } \\
\text { Exporting } \\
\text { Countries } \\
\end{array}$ & OAPEC & Safat (Kuwait) \\
\hline 153 & $\begin{array}{c}\text { Organization of } \\
\text { Central American } \\
\text { States }\end{array}$ & OCAS & San Salvador \\
\hline 154 & $\begin{array}{c}\text { Organization of the } \\
\text { Petroleum } \\
\text { Exporting } \\
\text { Countries } \\
\end{array}$ & OPEC & Vienna \\
\hline 155 & $\begin{array}{l}\text { Paris Club Creditor } \\
\text { Institutions }\end{array}$ & Paris Club & Paris \\
\hline 156 & $\begin{array}{c}\text { Publications Office } \\
\text { of the European } \\
\text { Union }\end{array}$ & POEU & Luxembourg \\
\hline 157 & $\begin{array}{c}\text { Single Resolution } \\
\text { Board }\end{array}$ & SRB & Brussels \\
\hline 158 & $\begin{array}{c}\text { South Asian } \\
\text { Association for } \\
\text { Regional } \\
\text { Cooperation } \\
\end{array}$ & SAARC & Kathmandu \\
\hline 159 & $\begin{array}{c}\text { Special } \\
\text { Development Fund } \\
\text { (related to the } \\
\text { Caribbean } \\
\text { Development } \\
\text { Bank) } \\
\end{array}$ & SDF & $\begin{array}{l}\text { St Michael } \\
\text { (Barbados) }\end{array}$ \\
\hline 160 & $\begin{array}{l}\text { The European } \\
\text { Union's Judicial } \\
\text { Cooperation Unit }\end{array}$ & EUROJUST & The Hague \\
\hline 161 & $\begin{array}{c}\text { Translation Centre } \\
\text { for the Bodies of } \\
\text { the European } \\
\text { Union }\end{array}$ & $\mathrm{CdT}$ & Luxembourg \\
\hline 162 & $\begin{array}{l}\text { United Nations } \\
\text { Children's Fund }\end{array}$ & UNICEF & New York \\
\hline 163 & $\begin{array}{c}\text { United Nations } \\
\text { Conference on } \\
\text { Trade and } \\
\text { Development } \\
\end{array}$ & UNCTAD & Geneva \\
\hline 164 & $\begin{array}{l}\text { United Nations } \\
\text { Educational, } \\
\text { Scientific and } \\
\text { Cultural } \\
\text { Organization } \\
\end{array}$ & UNESCO & Paris \\
\hline 165 & $\begin{array}{l}\text { United Nations, its } \\
\text { committees, funds } \\
\text { and programmes, } \\
\text { other }\end{array}$ & - & New York \\
\hline
\end{tabular}




\begin{tabular}{|c|c|c|c|}
\hline 166 & $\begin{array}{c}\text { Universal Postal } \\
\text { Union }\end{array}$ & UPU & Berne \\
\hline 167 & $\begin{array}{l}\text { West African } \\
\text { Central Bank }\end{array}$ & BCEAO & Dakar \\
\hline 168 & $\begin{array}{c}\text { West African } \\
\text { Economic and } \\
\text { Monetary Union }\end{array}$ & WAEMU & Ouagadougou \\
\hline 169 & $\begin{array}{l}\text { West African } \\
\text { Economic } \\
\text { Community }\end{array}$ & WAEC & Ouagadougou \\
\hline 170 & $\begin{array}{l}\text { West African } \\
\text { Health } \\
\text { Organisation } \\
\end{array}$ & WAHO & $\begin{array}{c}\text { Bobo-Dioulasso } \\
\text { (Burkina Faso) }\end{array}$ \\
\hline 171 & $\begin{array}{c}\text { West African } \\
\text { Monetary Agency }\end{array}$ & WAMA & $\begin{array}{c}\text { Freetown (Sierra } \\
\text { Leone) }\end{array}$ \\
\hline 172 & $\begin{array}{c}\text { West African } \\
\text { Monetary Institute }\end{array}$ & WAMI & Accra (Ghana) \\
\hline 173 & $\begin{array}{c}\text { World Council of } \\
\text { Churches }\end{array}$ & WCC & Geneva \\
\hline 174 & $\begin{array}{l}\text { World Health } \\
\text { Organization }\end{array}$ & WHO & Geneva \\
\hline 175 & $\begin{array}{c}\text { World Intellectual } \\
\text { Property } \\
\text { Organization }\end{array}$ & WIPO & Geneva \\
\hline 176 & $\begin{array}{c}\text { World } \\
\text { Meteorological } \\
\text { Organization }\end{array}$ & WMO & Geneva \\
\hline 177 & $\begin{array}{c}\text { World Tourism } \\
\text { Organization }\end{array}$ & UNWTO & Madrid \\
\hline 178 & $\begin{array}{l}\text { World Trade } \\
\text { Organization }\end{array}$ & WTO & Geneva \\
\hline
\end{tabular}




\title{
10. The diplomacy glossary
}

\author{
"A \\ abrogate, revoke formally \\ accession, the right to enter \\ accord, concurrence of opinion \\ accreditation, the act of granting official approval or recognition; \\ procedure by which a State, before sending an ambassador asks the State in which \\ this ambassador is to take up residence \\ acknowledge, declare to be true or admit the existence \\ adept, having or showing knowledge and skill and aptitude \\ adhere, stick to firmly \\ administrative and technical staff, in contrast to the diplomatic staff, the members of a \\ diplomatic mission working in the administrative or technical services do not enjoy \\ immunity in civil law courts and administrative tribunals insofar as their private \\ affairs are concerned \\ adversary, someone who offers opposition \\ adviser, an expert who gives advice \\ agency, the state of being in action or exerting power \\ agent, a representative who acts on behalf of others \\ allegiance, the loyalty that citizens owe to their country \\ alliance, the state of being confederated \\ ally, a friendly nation \\ ambassador, a diplomat of the highest rank \\ annex, attach to \\ annexation, incorporation by joining or uniting \\ announce, make known \\ appeasement, the act of acceding to demands \\ arbitration, giving authoritative judgment \\ attaché, a specialist assigned to the staff of a diplomatic mission \\ autonomous, existing as an independent entity"
}

"B

barter, exchange goods without involving money

bestow, give as a gift

betray, deliver to an enemy by treachery

bilateral, having two sides or parts

bilateralism, term used to describe discussions or negotiations on foreign policy matters that take place between two parties

border, the boundary of a surface

boycott, refusal to have commercial dealings with some organization

breach, an opening, especially a gap in a dike or fortification

broker, a businessman who buys or sells for another" 


\section{"C}

cartography, the making of maps and charts

channel, a deep and relatively narrow body of water

chargé d'affaires ad interim, the person who acts as head of mission (ambassador) when

the post is vacant, or when the ambassador is temporarily absent from the country

of residence or unable to perform his or her duties

charisma, personal attractiveness that enables you to influence others

claim, demand as being one's due or property

client, someone who pays for goods or services

collaboration, act of working jointly

collective, done by or characteristic of individuals acting together

compliance, the act of submitting, usually surrendering power to another

conciliatory, making or willing to make concessions

condemnation, an expression of strong disapproval

conduct, the way a person behaves toward other people

conflict, an open clash between two opposing groups

confront, oppose, as in hostility or a competition

conquer, take possession of by force, as after an invasion

consensus, the agreement on a given question. The consensus principle applies to decisions taken in the framework of international conferences and organisations

conspiracy, a plot to carry out some harmful or illegal act

consular, having to do with a consul or his office or duties

consular protection, consular protection enables a State to defend the rights of its citizens abroad

consulate, diplomatic building that serves as the residence or workplace of a consul convention, the act of meeting formally

cooperation, the practice of working together on a common enterprise

counterpart, a person or thing having the same function as another

courtesy, a considerate and respectful manner

covert, secret or hidden

credential, a document from the head of the sending State to the head of the receiving State attesting that the person designated as extraordinary and plenipotentiary ambassador is entitled by his government to perform the functions of head of mission

crisis, a crucial stage or turning point in the course of something

cunning, to show inventiveness and skill

customary, commonly used or practiced"

\section{"D}

declaration, a statement that is emphatic and explicit

declare, state emphatically and authoritatively

de facto, existing, whether with lawful authority or not 
defiance, a hostile challenge

deflect, turn from a straight course or fixed direction

delegation, a group of representatives

denounce, speak out against

deportment, the way a person behaves toward other people

dialogue, a conversation between two persons

diplomacy, negotiation between nations, the art or science of conducting such negotiations

diplomat, an official engaged in international negotiations

diplomatic, relating to negotiation between nations

diplomatic corps (CD), together, the heads of mission (Embassy) accredited to the same government form the diplomatic corps. It is presided over by the Dean (Doyen), who is normally the highest ranking head of mission, i.e. the head of mission who has been accredited to that country for the longest period

diplomatic courier, the person who carries official correspondence between a diplomatic mission (Embassy) and a ministry of Foreign Affairs as well as between other missions and consulates of the sending State

diplomatic protection, it allows a State to intervene on behalf of its nationals (individuals or legal entities) who have suffered prejudice of some kind at the hands of another State in violation of international law

displaced person, a person forced to flee from home or country

dispute, the act of coming into conflict

dissident, a person who objects to some established policy

doctrine, a belief accepted as authoritative by some group or school"

\section{"E}

embargo, a government order imposing a trade barrier

embassy, a building where diplomats live or work, referring both to the staff appointed by a State to carry out diplomatic functions in another State and to the premises in which this staff works

embolden, give encouragement to

emissary, someone sent on a mission to represent another's interests

endorsement, the act of approving

enforcement, to ensure observance of or obedience to

enlargement, the act of increasing in size or volume or quantity or scope

entanglement, an intricate trap that entangles or ensnares its victim

entity, that which is perceived to have its own distinct existence

envoy, a diplomat having less authority than an ambassador

envoy extraordinary, a diplomat having less authority than an ambassador

espionage, the systematic use of spies to obtain secrets

external, happening or arising outside some limits or surface

extradition, surrender of an accused by one State or country to another

extraordinary, serving an unusual or special function 
extraterritoriality, in principle, a law is effective only within the territory of the State which enacted it"

\section{"F}

facilitation, act of assisting the progress or improvement of something flagship, the ship that carries the commander of a fleet and flies his flag flux, a state of constant change

foe, an armed adversary

foreign policy, a policy governing international relations

foreign agent, a spy for a foreign country

foresight, seeing ahead; knowing in advance; foreseeing

forestall, keep from happening or arising; make impossible"

\section{"G}

geopolitics, the study of the effects of economic geography on the powers of the State gesture, motion of hands or body to emphasize a thought or feeling

goodwill, the friendly hope that something will succeed

grievance, a complaint about a wrong that causes resentment

grudging, petty or reluctant in giving or spending"

\section{"H}

helm, steering mechanism for a vessel

bindsight, understanding the nature of an event after it has happened

binterland, a remote and undeveloped area

honor, a tangible symbol signifying approval or distinction

hostile, characterized by enmity or ill will

buman rights, are the freedoms to which all individuals are entitled as human beings. Human rights are protected through a system of agreements as the Conventions, as the Resolutions and declarations at the international level as well as in customary international law"

\section{"I}

illicit, contrary to accepted morality or convention

immunity, an act exempting someone

immunity, diplomatic exemption from taxation or normal processes of law that is offered to diplomatic personnel in a foreign country

implement, a piece of equipment or a tool used for a specific purpose

impose, charge and collect payment

independence, freedom from control or influence of another or others

infringement, an act that disregards an agreement or a right

initiative, readiness to embark on bold new ventures

instructions, a manual explaining how to install or operate a device

instrument, the means whereby some act is accomplished 
insult, a deliberately offensive act

insurgence, an organized rebellion aimed at overthrowing a constituted government through the use of subversion and armed conflict

integrity, an undivided or unbroken completeness with nothing wanting

intelligence, the ability to comprehend

intercession, the act of intervening, as to mediate a dispute

interfere, get involved, so as to alter or hinder an action

interlocutor, a person who takes part in a conversation

international justice, to ensure universal respect for International law and Human rights, the international community has created various courts and tribunals at the universal and regional levels

international law, it governs relations between States and their dealings with each other intervene, be placed or located between other things

intervention, the act of interposing one thing between or among others

intimidation, the act of scaring a weaker person to make them do something

intrigue, a crafty and involved plot to achieve your ends

invasion, any entry into an area not previously occupied

isolated, remote and separate physically or socially"

"J

jeopardize, pose a threat to; present a danger to

"L

lame duck, an elected official still in office but not slated to continue

landlocked, surrounded entirely or almost entirely by land

leadership, the status of being in charge

league, an association of States or individuals for common action

lip service, an expression of agreement that is not supported by real conviction"

\section{"M}

maritime, relating to ships or navigation

measure, determine the dimensions of something or somebody

meddlesome, intrusive in an offensive manner

mediation, the act of intervening to bring about a settlement

memorandum, a written proposal or reminder. It is a written text summarising the essential facts relating to an international problem, also known as an "AideMemoire"

mercurial, liable to sudden unpredictable change

mission, an operation that is assigned by a higher headquarters

mollify, cause to be more favorably inclined

morality, the quality of being in accord with right or good conduct

mounting, an event that involves rising to a higher point 
multilateral, having many parts or sides"

$" \mathbf{N}$

negotiation, a discussion intended to produce an agreement

neutrality, it is the legal status of a State which permanently or temporarily renounces participation in any armed conflict. The Hague Conventions of 1907, supported by Customary international law, define the rights and duties of a neutral State nuncio, from the Latin for envoy, referring to the diplomatic representative of the Holy See, a titular bishop accredited as permanent ambassador to a foreign government"

\section{"O}

obsequious, attempting to win favor from influential people by flattery

ominous, threatening or foreshadowing evil or tragic developments

opt-out clause, it is a provision in an International treaty that allows a member State either to limit its obligations in special cases or allows temporary exemption. Optout (also protective) clauses are more common in economic treaties, and are intended as a kind of alarm

operation, activity by a military or naval force

onslaught, an offensive against an enemy

override, the act of nullifying

overseas, beyond or across the ocean"

"P

pact, a written agreement between two States or sovereigns partnership, a cooperative relationship between people or groups penchant, a strong liking

perfidious, tending to betray

permanent, continuing or enduring without marked change in status

perseverance, the act of persisting

persona, a personal facade that one presents to the world

persona non grata, a person who for some reason is not wanted or welcome

persuasion, communication intended to induce belief or action

plenipotentiary, a diplomat who is fully authorized to represent his or her government polite, showing regard for others in manners, speech, behavior, etc.

precedence, status established in order of importance or urgency

pressure, the exertion of force to a surface

prisoner of war, a person who surrenders to the enemy in time of war

privilege, a special advantage or benefit not enjoyed by all

proclaim, declare formally

protocol, forms of ceremony and etiquette observed by officials

punitive, inflicting punishment" 
Q

quarantine, isolation to prevent the spread of infectious disease

\section{"R}

react, show a response to something

rebuff, a deliberate discourteous act

reception, the act of taking in

reciprocal, concerning each of two or more persons or things

reciprocity, the principle of reciprocity plays a central role in international relations. In

practice this means that a State confers rights and advantages to another State only

in exchange for the same privileges

reckless, marked by defiant disregard for danger or consequences

recognition, identifying something or someone by remembering

recognize, perceive to be the same

reconnaissance, the act of scouting

regime, the governing authority of a political unit

rein, keep in check

relentless, never-ceasing

remittance, a payment of money sent to a person in another place

representation, standing in for someone and speaking on their behalf

representative, serving to typify

reservation, declaration made by a State party to a multilateral treaty by which it announces its intention to exclude or change the application of a clause in the treaty resolution, a decision to do something or to behave in a certain manner response, the speech act of continuing a conversational exchange restoration, returning something or someone to a satisfactory state restrain, hold back

rival, the contestant you hope to defeat

rogue state, a state that does not respect other States in its international actions rutbless, without mercy or pity"

\section{"S}

sanction, official permission or approval. All measures (diplomatic, economic or military) taken by a State or an International organisation to bring about an end to a violation of international law. Violations can either be noted by an organisation or by a State which considers itself to be a victim sardonic, disdainfully or ironically humorous

screening, testing objects or persons in order to identify those with particular characteristics

secure, free from danger or risk

settlement, something resolved; the outcome of decision making sphere of influence, the geographical area in which one nation is very influential shackle, bind the arms of 
smother, conceal or hide

sneer, a contemptuous or scornful remark

snub, refuse to acknowledge

solution, a homogeneous mixture of two or more substances

sovereignty, the authority of a State to govern another State

spy military, a secret agent hired by a state to obtain information about its enemies

stalemate, a situation in which no progress can be made

status, a state at a particular time

strain, exert much effort or energy

strategic, relating to an elaborate and systematic plan of action

strategist, an expert in systematic plans of action

struggle, strenuous effort

subsidiarity principle, principle according to which political decisions must be taken at a level as close as possible to the people

surveillance, close observation of a person or group"

\section{"T}

tact, consideration in dealing with others

tactic, a plan for attaining a particular goal

territory, a region marked off for administrative or other purposes

terrorist, a radical who advocates violence against civilians

thwart, hinder or prevent, as an effort, plan, or desire

tilt, a slight but noticeable partiality

track, a line or route along which something travels or moves

trade-off, an exchange that occurs as a compromise

transfer, move from one place to another

treaty, a formal agreement between two or more States in reference to peace, alliance, commerce, or other international relations

tribute, something given or done as an expression of esteem

trigger, lever that activates the firing mechanism of a gun

truce, a state of peace agreed to between opponents

trustworthy, worthy of trust or belief

turf war, a bitter struggle for territory or power or control or rights"

\section{"U}

ultimatum, a final peremptory demand

unctuous, unpleasantly and excessively suave or ingratiating

unilateral, involving only one part or side

upheaval, a violent disturbance

urge, force or impel in an indicated direction

urgency, an earnest and insistent necessity" 
"V

verity, conformity to reality or actuality

violate, fail to agree with; go against

vis-a-vis, a person or thing having the same characteristics as another"

\section{"W}

watchdog, a dog trained to guard property

watchful, engaged in or accustomed to close observation

withdrawn, tending to reserve or introspection"

See $A B C$ of Diplomacy, Swiss Federal Department of Foreign Affairs, 2008.

\section{References}

Berridge, G., and JAMES, A., (2001), A Dictionary of Diplomacy. Basingstoke, UK, Palgrave.

Berridge, G., and JAMES, A., (2005), Diplomacy: theory and practice, function of diplomacy, New York, Palgrave.

Craig, G., and Alexander, G., (1983), Force and Statecraft: Diplomatic Problems of Our Time. New York: Oxford University Press.

FDFA Switzerland, ABC of Diplomacy (2008), Swiss Federal Department of Foreign Affairs (FDFA), Zurich.

Figus A., (2011) Sistema Europa. L'organizzazione politica dell'Europa, Eurilink.

Figus A. (2013), La politica estera dell'Iran tra Occidente e crisi nucleare, Roma, Eurilink.

Halvard, L., (2016), A Conceptual History of Diplomacy, The Sage Handbook of Diplomacy.

Kissinger, H., (1994), Diplomacy. New York: Simon \& Schuster.

Lohmann, S., (2017), Understanding Diplomacy in the 21st Century, German Institute for International and Security Affairs.

Neumann, I., (2007) Globalisation and Diplomacy, Working paper, Norwegian Institute of International Affairs, Oslo, 2007.

\section{Web references}

[Online] Available: https://www.eda.admin.ch, ABC of Diplomacy, Swiss Federal Department of Foreign Affairs, 2008

[Online] Available: http://kamudiplomasisi.org/pdf/kitaplar/ adictionaryofdiplomacy.pdf

[Online] Available: http://contropiano.org/documenti/2017/01/06/la-guerra-mondiale-corsocoinvolti-47-paesi-087675

[Online] Available: https://europa.eu/european-union/index_en

[Online] Available: http://www.osce.org/it

[Online] Available: https://www.state.gov/documents/organization/176174.pdf

[Online] Available: www.ucdp.uu.se

[Online] Available: http://www.un.org/en/index.htm 